\author{
ACTA MYCOLOGICA \\ Vol. 46 (1): 83-107 \\ 2011
}

\title{
Geophilic dermatophytes and other keratinophilic fungi in the nests of wetland birds
}

\author{
TERESA KORNILŁOWICZ-KOWALSKA ${ }^{1}$, IGNACY KITOWSKI ${ }^{2}$ and HELENA IGLIK ${ }^{1}$ \\ ${ }^{1}$ Department of Environmental Microbiology, Mycological Laboratory \\ University of Life Sciences in Lublin \\ Leszczyńskiego 7, PL-20-069 Lublin, teresa.kornilowicz@up.lublin.pl \\ ${ }^{2}$ Department of Zoology, University of Life Sciences in Lublin, Akademicka 13 \\ PL-20-950 Lublin, ignacyk@autograf.pl
}

Korniłłowicz-Kowalska T., Kitowski I., Iglik H.: Geophilic dermatophytes and otherkeratinophilic fungi in the nests of wetland birds. Acta Mycol. 46 (1): 83-107, 2011.

The frequency and species diversity of keratinophilic fungi in 38 nests of nine species of wetland birds were examined. Nine species of geophilic dermatophytes and 13 Chrysosporium species were recorded. Ch. keratinophilum, which together with its teleomorph (Aphanoascus fulvescens) represented $53 \%$ of the keratinolytic mycobiota of the nests, was the most frequently observed species. Chrysosporium tropicum, Trichophyton terrestre and Microsporum gypseum populations were less widespread. The distribution of individual populations was not uniform and depended on physical and chemical properties of the nests (humidity, $\mathrm{pH}$ ).

Key words: Ascomycota, mitosporic fungi, Chrysosporium, occurrence, distribution

\section{INTRODUCTION}

Geophilic dermatophytes and species representing the Chrysosporium group (an arbitrary term) related to them are ecologically classified as keratinophilic fungi. Keratinophilic fungi colonise keratin matter (feathers, hair, etc., animal remains) in the soil, on soil surface and in other natural environments. They are keratinolytic fungi physiologically specialised in decomposing native keratin. They fully solubilise native keratin (chicken feathers) used as the only source of carbon and energy in liquid cultures after 70 to 126 days of growth $\left(20^{\circ} \mathrm{C}\right)$ (Korniłłowicz-Kowalska 1997). Fungi other than dermatophytes and Chrysosporium decompose only 30\%-33\% of native feather keratin in the same period (Korniłłowicz-Kowalska l.c.). According to Kunert (2000), fungi are weakly keratinolytic if they decompose no more than $40 \%$ of keratin in liquid cultures after eight weeks and non-keratinolytic if they decompose 
less than $20 \%$. Native keratin substrates contain both keratin as well as simpler compounds, e.g., non-keratin proteins, amino acids, urea, which constitute up to $10 \%$ of the substrate's dry weight (Mercer 1958). This allows a range of other fungi that are de facto non-keratinolytic to grow on native keratin (Korniłłowicz 1992).

Geophilic dermatophytes are represented by the genera Trichophyton Malmsten and Microsporum Gruby (anamorphs) and by their respective teleomorphs: Arthroderma Berk. and Nannizzia Stocklade. The Chrysosporium group comprises two keratinolytic genera: Chrysosporium Corda and Myceliophthora Cost (anamorphs). Their teleomorphs are classified in the genera Arthroderma Berk., Aphanoascus Zukal and Ctenomyces Eidam. or remain unknown (van Oorschot 1980; Currah 1985). Representatives of both groups of fungi in the holomorphic stage are included in Onygenales (Ascomycota) and in the anamorphic stage in Hyphomycetales (mitosporic fungi) (Currah 1985; Korniłłowicz-Kowalska, Wojdyło-Kotwica 2008).

Some species of ubiquistic moulds (polyphages), and especially Aspergillus fumigatus and Scopulariopsis brevicaulis, also show keratinolytic abilities according to some authors (Santos et al. 1996; Filipello-Marchisio et al. 2000)

Keratinophilic fungi are potentially pathogenic saprotrophs described as opportunistic pathogens (Rippon 1982). Pathogenic strains of these fungi, in particular species such as Microsporum gypseum, M. cookei, Chrysosporium keratynophilum, cause dermatomycoses in humans and animals. Ubiquistic moulds with keratinolytic abilities are causal agents of opportunistic mycoses such as systemic mycoses (A. fumigatus) or superficial mycoses, e.g., nail mycoses (S. brevicaulis) (Dvořak, Otčenašek 1969).

The biodegradation of native keratin, a protein resistant to the attack of ordinary proteolytic enzymes, works as the enzymatic lysis combined with a mechanical destruction aided by the eroding mycelium complex (English 1963, 1965; Kunert 1989, 2000). In dermatophytes, it consists of the so-called frond mycelium, which erodes the substrate surface, and multicellular perforating organs penetrating the substrate and secreting keratinolytic enzymes (English 1963, 1965; Kunert 2000). Keratinolytic Chrysosporium species produce simpler penetrative structures that are single, apically swollen hyphae known as boring hyphae (English 1963, 1965). Ch. keratinophilum, which produces penetrative hyphae resembling multicellular organs in dermatophytes, is an exception (English 1969). Keratinolytic Chrysosporium species usually decompose native keratin more slowly than geophilic dermatophytes (Korniłłowicz-Kowalska 1997; Filipello-Marchisio 2000).

Ubiquistic moulds produce only thin and simple boring hyphae when growing on native keratin substrates (English 1965).

The process of fungal keratinolysis consists of three stages: deamination, sulphitolysis and proteolysis (Kunert 2000). Deamination leads to the release of ammonia conditioned by a high nitrogen level in native keratin: from $14.72 \%$ in feathers (Korniłłowicz-Kowalska 1997) to $16 \%$ in hair (Kunert 2000), and a narrow C:N ratio in these substrates, such as 3:1 for feathers (Korniłłowicz-Kowalska 1.c.). $\mathrm{N}_{-} \mathrm{NH}_{4}{ }^{+}$ accumulation causes environment alkalisation necessary for enzymatic disruption of greatly numerous keratin disulphide bridges responsible for its resistance to the activity of proteolytic enzymes. Sulphitolysis, that is the process of the disruption of S-S bonds, occurs with the participation of inorganic sulphite produced by the fungus (Kunert 1973, 1976). This leads to keratin denaturation and, consequently, 
makes proteolysis with alkaline or neutral proteases of these fungi possible (Kunert 2000).

During saprotrophic growth on native keratin, keratinolytic fungi oxidize $70 \%$ of carbon to $\mathrm{CO}_{2}$, release $70-80 \%$ of nitrogen as ammonia and transform $30-50 \%$ of sulphur into sulphates (Korniłłowicz-Kowalska 1997). This allows keratinolytic fungi to play an important role in the recycling of carbon, nitrogen, sulphur of animal remains containing keratin.

The occurrence of keratinophilic fungi in natural environments is conditioned primarily by their "animialisation" related to an inflow of keratin matter (Montovani et al. 1982). Keratin remnants are not only a nutritive source for the fungi but also a specific habitat enabling their survival and defence from other competitive microorganisms (Garetta, Piontelli 1975). The species diversity of keratinomycetes also depends on various physical and chemical properties of the environment, mostly pH, humidity and temperature (Bőhme, Ziegler 1969; Chmel et al. 1972; Chmel, Vláčiliková 1975; Garg et al. 1985; Kushwaha 2000; Korniłłowicz-Kowalska, Bohacz 2002).

Birds' nests which usually contain considerable amounts of keratin matter (feathers, hair, pellets, prey remains) and have different levels of humidity and $\mathrm{pH}$ are therefore interesting microhabitats in this regard (Pugh, Evans 1970; Hubalek 1974, 2000; Korniłłowicz-Kowalska, Kitowski 2009).

Nests of terrestrial birds, in particular passerine Passeriformes, were mostly examined in studies (conducted chiefly between 1960 and 1980) on the occurrence and distribution of geophilic dermatophytes and species of Chrysosporium group related to them (Pugh 1966; Otčenašek et al. 1967; Pugh, Evans 1970; Hubalek et al. 1973; Hubalek 1974, 1976; Hubalek, Balat 1974; Tokatori, Hasegawa 1981). Investigations on the keratinolytic mycobiota of nests of birds associated with aquatic habitats are fragmentary (Hubalek 1974; Korniłłowicz-Kowalska, Kitowski 2009).

As the participation of wetland birds in the distribution of various pathogenic micro-organisms, including opportunistic pathogens causing mycoses in birds, mammals and humans has been on the increase in recent years (Hubalek 2004), there is a need to expand studies on the occurrence and distribution of keratinophilic fungi in breeding and feeding biotopes of these birds. Such research will contribute to a better knowledge of the role of these habitats in the survival and, partly, transmission of potentially pathogenic keratinophilic fungi.

The aim of this study was to identify the species composition and the frequency of geophilic dermatophytes and Chrysosporium representatives in the nests of different species of wetland birds in connection with some physical and chemical properties of those nests.

\section{MATERIAL AND METHODS}

Nests: location, building material and structure. Nests of nine bird species in southeast Poland (the Lublin region) were examined. A total of 38 nests were studied. The nests were collected in the period between 2006 and 2008 after they had been 
abandoned by birds. Only nests of grey herons (Ardea cinerea) were situated in the trees; the nests of other birds were in reeds and rushes of water bodies (ponds, a lake) in other aquatic vegetation or were floating nests (Tab. 1).

The nests were built from plant material and contained various amounts of nonplant material which was partly used to line the nest (feathers, hair) and was partly secondary (shed feathers, food remains, etc.) (Tab. 2).

Nests of marsh harriers (Circus aeruginosus) were $50-90 \mathrm{~cm}$ in diameter and were partly above the water surface (ca. $50 \mathrm{~cm}$ under water and ca. $70 \mathrm{~cm}$ above water). The nests were stable, non-floating, situated in reed beds of the common reed (Phragmites australis) or rushes of the broadleaf cattail (Typha latifolia). The base of the nests was built from twigs of black alder (Alnus glutinosa), downy birch (Betula pubescens) and other birches (Betula sp.) as well as willows (Salix sp.). Nest edges were sometimes supported with stems of burdock (Arctium sp.) and creeping thistle (Cirsium arvense). The lining, easily distinguishable from the rest of the nest, was built from common reeds and broadleaf cattails, supplemented with sedges Carex sp. and Poacae grasses difficult to identify due to rotting. The lining also contained great nettle (Urtica dioica), great bulrush (Schoenoplectus lacustris), sometimes rhizomes of weed grass Agropyron sp. and other unidentified small roots. Material of animal origin constituted much of the lining: pellets of adult and young birds containing mammal hair, bird feathers, other undigested parts of the prey and prey bones; remains of uneaten prey containing hair of small mammals Micromammalia,

Table 1

Bird species, nest location and collection date

\begin{tabular}{|c|c|c|c|c|c|}
\hline No & Bird species & $\begin{array}{l}\text { Systematic } \\
\text { classification } \\
\text { (order, family) }\end{array}$ & $\begin{array}{l}\text { Number } \\
\text { of nests }\end{array}$ & $\begin{array}{l}\text { Nesting } \\
\text { site }\end{array}$ & Collection place and date \\
\hline 1 & $\begin{array}{l}\text { Marsh harrier } \\
\text { Circus aeruginosus L. }\end{array}$ & $\begin{array}{l}\text { Falconiformes } \\
\text { Accipitridae }\end{array}$ & 3 & Ponds & $\begin{array}{c}\text { Zalesie Kraszeńskie (1) } \\
\text { 11.07.2006 } \\
\text { Nieledew (2) } \\
04.07 .06 \\
12.07 .06\end{array}$ \\
\hline 2 & $\begin{array}{l}\text { Grey heron } \\
\text { Ardea cinerea L. }\end{array}$ & $\begin{array}{l}\text { Ciconiformes } \\
\text { Ardeidae }\end{array}$ & 6 & $\begin{array}{l}\text { Heronries } \\
\text { small } \\
\text { forest } \\
\end{array}$ & $\begin{array}{c}\text { Chodlik (2) } 2007 \\
\text { Dołhobrody (4) } 2007\end{array}$ \\
\hline 3 & $\begin{array}{l}\text { Mute swan } \\
\text { Cygnus olor Gmel. }\end{array}$ & $\begin{array}{l}\text { Anseriformes } \\
\text { Anatidae }\end{array}$ & 5 & Ponds & $\begin{array}{c}\text { Swięcica (1) 02.08.07 } \\
\text { Garbów (1) } 18.07 .07 \\
\text { Piaski (1) 02.08.07 } \\
\text { Stary Brus (2) } 17.07 .07\end{array}$ \\
\hline 4 & $\begin{array}{l}\text { Coot } \\
\text { Fulica atra } \mathrm{L} .\end{array}$ & $\begin{array}{l}\text { Gruiformes } \\
\text { Rallidae }\end{array}$ & 5 & Ponds & $\begin{array}{c}\text { Garbów } \\
17.07 .07(3) \\
18.0707(2)\end{array}$ \\
\hline 5 & $\begin{array}{l}\text { Great crested grebe } \\
\text { Podiceps cristatus L. }\end{array}$ & $\begin{array}{l}\text { Podicipediformes } \\
\text { Podicipedidae }\end{array}$ & 5 & Ponds & $\begin{array}{c}\text { Garbów (1) 11.07.08 } \\
\text { Samoklęski (2) 31.07.08 } \\
\text { Ștańków (1) 19.07.07 } \\
\text { Zółtańce (1) 22.07.07 }\end{array}$ \\
\hline 6 & $\begin{array}{l}\text { Black-headed gull } \\
\text { Larus ridibundus L. }\end{array}$ & $\begin{array}{l}\text { Charadriformes } \\
\text { Laridae }\end{array}$ & 7 & $\begin{array}{l}\text { Ponds } \\
\text { Setters }\end{array}$ & $\begin{array}{l}\text { Garbów (1) 17.07.07 } \\
\text { Garbów (3) 11.07.08 } \\
\text { Garbów (3) } 11.07 .08 \\
\end{array}$ \\
\hline 7 & $\begin{array}{l}\text { Common gull } \\
\text { Larus canus } \mathrm{L} .\end{array}$ & $\begin{array}{l}\text { Charadriformes } \\
\text { Laridae }\end{array}$ & 1 & Lake & J. Wytyckie (1) 15.08 .08 \\
\hline 8 & $\begin{array}{l}\text { Common tern } \\
\text { Sterna hirundo L. }\end{array}$ & $\begin{array}{l}\text { Charadriformes } \\
\text { Sternidae }\end{array}$ & 5 & Lake & J. Wytyckie (5) 15.08 .08 \\
\hline 9 & $\begin{array}{l}\text { Black tern } \\
\text { Chlidonias niger } \mathrm{L} \text {. }\end{array}$ & $\begin{array}{l}\text { Charadriformes } \\
\text { Sternidae }\end{array}$ & 1 & Pond & Stańków (1) 18.07.07 \\
\hline
\end{tabular}


Table 2

Animal matter ratio in the nest structure (in relation to the nest mass)

\begin{tabular}{|c|c|c|c|c|c|}
\hline No & Bird species & Feathers & $\begin{array}{l}\text { Romains of } \\
\text { animal food }\end{array}$ & Pellets & Excrements \\
\hline 1 & $\begin{array}{l}\text { Marsh harrier } \\
\text { Circus aeruginosus L. }\end{array}$ & $\mathrm{H}$ & $\mathrm{H}$ & $\mathrm{H}$ & $\mathrm{H}$ \\
\hline 2 & $\begin{array}{l}\text { Grey heron } \\
\text { Ardea cinerea L. }\end{array}$ & $\mathrm{S}$ & $\mathrm{S}$ & A & $\mathrm{H}$ \\
\hline 3 & $\begin{array}{l}\text { Mute swan } \\
\text { Cygnus olor Gmel. }\end{array}$ & $\mathrm{H}$ & $\mathrm{A}$ & A & $\mathrm{H}$ \\
\hline 4 & $\begin{array}{l}\text { Coot } \\
\text { Fulica atra L. }\end{array}$ & $\mathrm{S}$ & A & A & $\mathrm{S}$ \\
\hline 5 & $\begin{array}{l}\text { Great crested grebe } \\
\text { Podiceps cristatus L. }\end{array}$ & $\mathrm{S}, \mathrm{A}$ & $\mathrm{S}, \mathrm{A}$ & A & $\mathrm{S}$ \\
\hline 6 & $\begin{array}{l}\text { Black-headed gull } \\
\text { Larus ridibundus L. }\end{array}$ & $\mathrm{S}$ & $\mathrm{S}$ & A & A \\
\hline 7 & $\begin{array}{l}\text { Common gull } \\
\text { Larus canus L. }\end{array}$ & $\mathrm{S}$ & $\mathrm{S}$ & A & $\mathrm{S}$ \\
\hline 8 & $\begin{array}{l}\text { Common tern } \\
\text { Sterna hirundo L. }\end{array}$ & $\mathrm{S}$ & $\mathrm{S}$ & $\mathrm{A}$ & $\mathrm{S}$ \\
\hline 9 & $\begin{array}{l}\text { Black tern } \\
\text { Chlidonias niger } \mathrm{L} .\end{array}$ & $\mathrm{S}$ & A & A & A \\
\hline
\end{tabular}

Abbreviation: $\mathrm{H}$ - high; S - small; A - absent

lagomorphs Lagomorpha, skin, tails and limbs of lizards Lacertilia, birds' wings and feathers (included poultry); chick down; adult birds' feathers (females moulting during incubation period); chick excrements (the marsh harrier is an altricial bird); less often wings of orthopterans Orthoptera or fish scales (dead carp Cyprinus carpio).

Both plant and non-plant components of the nests' building material were highly compressed because of the birds' presence in the nests and formed a fixed structure.

Nests of grey herons (Ardea cinerea) were in a heronry in the crowns of tall trees. The base of the nests (a loose cone) was built from thicker sticks; the inner part was built from flexible twigs of deciduous trees: birch (Betula sp.), willow (Salix sp.) and alder (Alnus sp.). The nest lining was sparse, mostly composed of grasses (Poacae), various unidentified small roots as well as hair, feathers and fish scales. The lining was absent in some nests. The nest structure was covered with a high amount of white excrements on the inside and the outside as chicks (altricial birds) defecate inside the nest.

Nests of mute swans (Cygnus olor) were recorded on the edge of reed beds of the common reed (Phragmites australis) and rushes of the broadleaf cattail (Typha latifolia). The nests were stable, large, spherical, $95-161 \mathrm{~cm}$ in diameter, $60-140 \mathrm{~cm}$ high, at ca. $60 \mathrm{~cm}$ immersed in water, wet. The lining was indistinguishable from the rest of the nest due to rotting. The nests were built mostly from rotting parts of the common reed (Phragmites australis) and cattails Typha sp. as well as willow twigs (Salix sp). Non-plant material consisted of high amounts of excrements of chicks and adult birds as well as chick eider as chicks spend much time in the nest (although the mute swan is a precocial bird), feathers of adult birds, shells and membranes of hatched eggs (birds do not remove eggshells from the nests).

Nests of coots (Fulica atra) similary to the nests of mute swans were recorded in reed beds of the common reed (Phragmites australis) and rushes of the broadleaf cattail (Typha latifolia) similarly to the nests of mute swans. They were not very big: 
24-31 cm, spherical, equipped with a type of "pier" providing easier access to water. They were mostly built from stems of broadleaf cattail (Typha latifolia) with an addition of sweet flag (Acorus calamus), fennel pondweed (Potamogeton pectinatus), sporadically containing twigs of black alder (Alnus glutinosa) and poplar (Populus sp.). The inside of the nests was lined with leaves of common reeds (Phragmites australis) and grasses (Poacae) poorly distinguishable from the rest of the nest. Very small amounts of feathers and faeces in comparison with those recorded in the nests of mute swans were observed.

Nests of great crested grebes (Podiceps cristatus) were recorded on the edge of a Phragmites australis reed bed growing on pond banks. They were unstable, floating, quite large, 40-68 cm in diameter, $10-19 \mathrm{~cm}$ high, mount-like in shape. Most of the nest structure was immersed in water; only a layer of 4-7 cm was above the water surface. The lining was hardly distinguishable from the rest of the nest. The nests were built from rotten plant material in which perennial dicots, a small amount of Canadian waterweed (Elodea canadensis), rushes (Typha latifolia) and fennel pondweed (Potamogeton pectinatus) were identified. More permanent plant material consisting of common reeds (Phragmites australis) formed the base of the nest. Animal material was rarely found in the nest structure: fish scales and bird feathers. Excrements were not found (a precocial bird).

Nests of black-headed gulls (Larus ridibundus) nesting in colonies and in setters were recorded in the centre of broadleaf cattail rushes (Typha latifolia). The nests were stable, mound-like, quite dry, $27-55 \mathrm{~cm}$ in diameter, $7-24 \mathrm{~cm}$ high. They were mostly built from remains of aquatic plants, usually broadleaf cattail Typha sp. and common reed (Phragmites australis). The base was made of twigs of willow Salix sp., black alder Alnus glutinosa, downy birch Betula pubescens, other birches (Betula sp.) and European black elderberry Sambucus nigra. Rhizomes of Agropyron sp., reed leaves and water horsetail (Equisetum fluviatile) were recorded in the lining which was not always well distinguished from the rest of the nest. Very small amounts of feathers and fish scales were found in the nest structure.

The nest of common gulls (Larus canus) nesting on a lake was recorded on a floating island built from rotten vegetation. The nest was mound-shaped, ca. $30 \mathrm{~cm}$ in diameter, consisting of rotten, unidentifiable vegetation. It contained very few feathers and little excrements.

Nests of common terns (Sterna hirundo) were recorded on floating vegetation, mostly water lilies (Nymphaea sp. and Nuphar sp.). They were also mound-shaped, ca. $20 \mathrm{~cm}$ in diameter. They consisted of rotten, unidentifiable vegetation. They contained very few feathers and slightly more excrements than the gull's nest.

The nest of black tern (Chlidonias niger) nesting in rushes of Typha sp. The nest was a small mound (ca. $20 \mathrm{~cm}$ in diameter) made of broken stems of reeds and rushes. The nest did not have any excrements and had very few feathers.

Isolation and identification of fungi. Keratinophilic fungi were isolated with the keratin baiting method using white chicken feathers as the substrate. A total of 390 plates were made. Plates were filled with the nest material broken into smaller pieces to $1 / 2$ and sterile feathers were placed on top. Feathers were sterilised using the method of ethylene oxide gassing as described in a study by Korniłłowicz (1994). Ten plates were prepared from each nest with the exception of nest 2 (Circus aeruginosus) from which 20 plates were prepared. Nest material ranging from 200 to $500 \mathrm{~g}$ was selected 
randomly from ten different sites in the nest when the brood chamber was poorly defined or not evident or from its three layers (nest 2, Circus aeruginosus) comprising the lining, the outer layer and the layer in between (middle layer) (Pugh 1966).

Plates with the nest material were placed in a humidity chamber and incubated at $26^{\circ} \mathrm{C}$ for tree to four weeks. The forming mycelium layers were plated onto plates with Sabouraud glucose agar with actidion and chloramphenicol obtaining clean fungal cultures by passage.

The genus and the species of the fungi were identified using macroscopic characters on plates or microscopic characters in microcultures. Preparations of the mycelium developed on feathers were made in a drop of water to identify teleomorphs, which was particularly important for heterotallic species. The fungi were determined using systematic studies by: Ellis (1971); Domsch et al. (1980); van Oorschot (1980); Currah (1985); Peberdy (1987).

Determination of physical and chemical properties of the nests. Water content in the nest material was determined with the weight method at $105^{\circ} \mathrm{C} . \mathrm{pH}$ in $\mathrm{H}_{2} \mathrm{O}$ and $\mathrm{KCl}$ were measured potentiometrically. Total carbon and total sulfur content was determined with an elemental analysis by combustion analysis and in a thermal conductivity detector, $\mathrm{C}$ organic content by Thiurin method. The content of total N, total $\mathrm{P}, \mathrm{K}, \mathrm{Ca}, \mathrm{Mg}$ was determined after sample mineralisation using the wet assay method in a mixture of concentrated $\mathrm{H}_{2} \mathrm{SO}_{4}$ and perhydrol using flow spectrophotometry (N-tot., P-tot.) and with the atomic absorption spectroscopy method (K, Ca, $\mathrm{Mg})$.

Results assessment. The number of plates (samples) with the nest material showing growth of keratinophilic and non-keratinophilic fungi (an arbitrary term) was used for the general assessment of the occurrence frequency of fungi. It was accepted that one plate can be colonised by only one strain of a fungal species.

The species diversity of fungi based on the number of isolates of fungi representing individual species was analysed by calculating Simpson's index (Krebs 1994) according to the formula:

$$
\mathrm{D}=1-\sum_{\mathrm{i}=1}^{\mathrm{s}}\left(\mathrm{p}_{\mathrm{i}}^{2}\right)
$$

where $\mathrm{p}_{\mathrm{i}}$ is the share of isolates (strains) of species , $\mathrm{i}$ ” in a fungal community and is the quotient of the number of strains of the species and the number of isolates of all fungi obtained on an isolation medium. Values of Simpson's index range from 0 to $1-1 / \mathrm{S}$, where $\mathrm{S}$ is the number of species in a community of fungi.

The species dominance (Trojan 1975) was determined using the formula $\mathrm{D}=$ 100 . (Sa : S) where $\mathrm{Sa}$ - the sum of isolates of species a, $\mathrm{S}-$ the sum of isolates of the group. The group dominance (geophilic dermatophytes and Chrysosporium) was determined in a similar way, where $\mathrm{Sa}$ - the sum of isolates in a group, $\mathrm{S}-$ the sum of isolates of all fungi.

The following scale was used to assess the frequency of species and groups of keratinophilic fungi: < 1\% sporadically; $1-5 \%$ rarely; $6-25 \%$ frequently; $26-50 \%$ very frequently; $>50 \%$ mass occurrance.

Correlation coefficients (r) were calculated to define the relationship between the frequency of dominant fungal species and some physical and chemical properties of the nests. 


\section{RESULTS}

Physical and chemical properties of the nests. The analysis shows (Tab. 3 ) that the level of humidity was very high and exceeded $80 \%$ in the majority of the nests (30 out of 38). Lower humidity was recorded only in the nests of grey heron and marsh harrier. A probably secondary increase of humidity was observed in the majority of the nests of grey heron (no 4-8) collected from the ground surface where they had fallen after a storm. The $\mathrm{pH}$ of the nests was close to neutral or slightly alkaline

Table 3

Humidity level (in \% of dry weight) and $\mathrm{pH}$ level in the nests

\begin{tabular}{|c|c|c|c|c|}
\hline \multirow[t]{2}{*}{ Nest no } & \multirow[t]{2}{*}{ Bird species } & \multicolumn{2}{|c|}{$\mathrm{pH}$} & \multirow[t]{2}{*}{ Humidity } \\
\hline & & $\mathrm{H}_{2} \mathrm{O}$ & $\mathrm{KCl}$ & \\
\hline 1 & \multirow[t]{5}{*}{ Marsh harrier } & 6.95 & 7.44 & 70.54 \\
\hline $2-I$ & & 7.20 & 7.44 & 76.91 \\
\hline 2 -II & & 6.70 & 6.81 & 61.42 \\
\hline 2-III & & 5.89 & 6.34 & 49.58 \\
\hline 3 & & 7.23 & 6.24 & 49.56 \\
\hline 4 & \multirow[t]{6}{*}{ Grey heron } & 7.41 & 6.49 & 58.19 \\
\hline 5 & & 6.83 & 5.52 & 62.3 \\
\hline 6 & & 6.47 & 5.26 & 50.98 \\
\hline 7 & & 5.99 & 5.46 & 64.76 \\
\hline 8 & & 7.49 & 6.82 & 45.67 \\
\hline 9 & & 7.76 & 6.90 & 18.78 \\
\hline 10 & \multirow[t]{5}{*}{ Mute swan } & 6.54 & 6.44 & 87.72 \\
\hline 11 & & 7.10 & 7.08 & 82.57 \\
\hline 12 & & 6.92 & 6.90 & 90.61 \\
\hline 13 & & 7.02 & 6.23 & 80.72 \\
\hline 14 & & 6.55 & 5.64 & 78.44 \\
\hline 15 & \multirow[t]{5}{*}{ Coot } & 6.82 & 6.86 & 88.31 \\
\hline 16 & & 7.14 & 7.34 & 86.71 \\
\hline 17 & & 6.70 & 5.95 & 84.57 \\
\hline 18 & & 7.04 & 6.99 & 84.17 \\
\hline 19 & & 6.90 & 6.74 & 88.47 \\
\hline 20 & \multirow{7}{*}{$\begin{array}{l}\text { Black-headed } \\
\text { gull }\end{array}$} & 7.57 & 7.32 & 44.09 \\
\hline 26 & & 7.15 & 7.14 & 85.67 \\
\hline 27 & & 7.25 & 7.04 & 87.33 \\
\hline 28 & & 7.20 & 7.08 & 85.54 \\
\hline 29 & & 6.84 & 7.22 & 86.55 \\
\hline 30 & & 6.87 & 6.78 & 78.68 \\
\hline 31 & & 6.72 & 6.63 & 76.21 \\
\hline 36 & Common gull & 6.84 & 6.76 & 85.26 \\
\hline 21 & \multirow{5}{*}{$\begin{array}{l}\text { Great crested } \\
\text { grebe }\end{array}$} & 7.23 & 6.95 & 85.34 \\
\hline 22 & & 7.10 & 7.36 & 86.79 \\
\hline 23 & & 7.20 & 6.85 & 88.06 \\
\hline 24 & & 7.47 & 6.95 & 90.11 \\
\hline 32 & & 6.90 & 6.87 & 79.64 \\
\hline 25 & Common tern & 6.47 & 7.17 & 82.16 \\
\hline 33 & \multirow[t]{5}{*}{ Black tern } & 7.15 & 6.89 & 85.84 \\
\hline 34 & & 7.34 & 7.05 & 86.08 \\
\hline 35 & & 7.30 & 7.08 & 85.02 \\
\hline 37 & & 7.10 & 6.80 & 85.60 \\
\hline 38 & & 6.90 & 6.63 & 85.85 \\
\hline
\end{tabular}

Abbreviations: 1 - the outer layer of the nest; 2 - the intermediate layer of the nest; 3 - the inner layer (lining) of the nest 
( $\mathrm{pH}$ in $\mathrm{H}_{2} \mathrm{O}$ 6.55-7.76) with the exception of one nest of grey heron (no 7) where a weakly acidic $\mathrm{pH}$ was recorded ( $\mathrm{pH}$ in $\mathrm{H}_{2} \mathrm{O}$ 5.99) (Tab. 3).

The level of total carbon and organic carbon recorded in the nest material varied (Tab. 4). C organic content (in \% of dry weight) ranged from $24.1 \%$ to $47.9 \%$. Total $\mathrm{N}$ level was high or sometimes very high ranging from $1.28 \%$ d.w. to $5.38 \%$ d.w. A high content of total $\mathrm{N}$ was particularly high in the nests of grey heron: $2.29 \%$ $5.38 \%$, which should be attributed to the accumulation of excrements from young birds. Different levels of phosphorus and calcium were recorded in the nests. A very high phosphorus content (7.2\% d.w.) was observed only in some nests of grey heron. A high level of calcium, as high as $6.92 \%$ d.w., was recorded in some nets of mute swan, great crested grebes, black-headed gull and common tern. Total S content

Table 4

The content of some macroelements (in \% of dry weight) in the nest material

\begin{tabular}{|c|c|c|c|c|c|c|c|c|c|}
\hline \multirow{2}{*}{$\begin{array}{c}\text { Nest } \\
\text { number }\end{array}$} & \multirow{2}{*}{$\begin{array}{l}\text { Bird } \\
\text { species }\end{array}$} & \multicolumn{8}{|c|}{ Macroelement content ( $\%$ of the nest dry weight) } \\
\hline & & $\begin{array}{c}\mathrm{C} \\
\text { total }\end{array}$ & $\begin{array}{c}\mathrm{C} \\
\text { organic }\end{array}$ & $\begin{array}{c}\mathrm{N} \\
\text { total }\end{array}$ & $\begin{array}{c}\mathrm{S} \\
\text { total }\end{array}$ & $\begin{array}{c}\mathrm{P} \\
\text { total }\end{array}$ & $\mathrm{K}$ & $\mathrm{Ca}$ & $\mathrm{Mg}$ \\
\hline 1 & \multirow{3}{*}{$\begin{array}{l}\text { Marsh } \\
\text { harrier }\end{array}$} & 45.68 & 43.95 & 2.17 & 0.28 & 0.15 & 0.19 & 0.70 & 0.043 \\
\hline 2 & & 46.92 & 42.27 & 2.27 & 0.31 & 0.23 & 0.40 & 0.59 & 0.129 \\
\hline 3 & & 47.24 & 42.44 & 2.17 & 0.40 & 0.09 & 0.10 & 0.47 & 0.030 \\
\hline 4 & \multirow[t]{6}{*}{ Grey heron } & 36.84 & 32.30 & 3.47 & 0.61 & 7.20 & 0.89 & 6.10 & 0.309 \\
\hline 5 & & 43.94 & 37.48 & 2.35 & 0.40 & 4.98 & 0.40 & 4.08 & 0.236 \\
\hline 6 & & 43.40 & 35.19 & 3.06 & 0.46 & 6.07 & 0.36 & 4.83 & 0.219 \\
\hline 7 & & 41.00 & 36.02 & 2.89 & 0.48 & 3.50 & 0.29 & 5.81 & 0.187 \\
\hline 8 & & 49.10 & 40.74 & 2.29 & 0.34 & 0.83 & 0.55 & 2.03 & 0.141 \\
\hline 9 & & 47.46 & 39.23 & 5.38 & 0.47 & 0.78 & 1.19 & 1.49 & 0.106 \\
\hline 10 & \multirow[t]{5}{*}{ Mute swan } & 47.53 & 43.88 & 2.72 & 0.47 & 0.21 & 0.53 & 2.15 & 0.216 \\
\hline 11 & & 37.62 & 33.18 & 1.87 & 0.31 & 0.20 & 0.11 & 6.92 & 0.105 \\
\hline 12 & & 44.93 & 40.95 & 2.02 & 0.33 & 0.21 & 0.12 & 3.32 & 0.055 \\
\hline 13 & & 48.23 & 45.16 & 1.79 & 0.25 & 0.13 & 0.37 & 1.18 & 0.064 \\
\hline 14 & & 41.70 & 40.19 & 2.07 & 0.26 & 0.11 & 0.14 & 0.43 & 0.040 \\
\hline 15 & \multirow[t]{5}{*}{ Coot } & 47.66 & 44.75 & 1.60 & 0.28 & 0.16 & 0.28 & 1.27 & 0.177 \\
\hline 16 & & 47.75 & 43.85 & 2.53 & 0.37 & 0.25 & 0.40 & 1.94 & 0.256 \\
\hline 17 & & 45.14 & 39.92 & 2.57 & 0.82 & 0.18 & 0.10 & 1.32 & 0.249 \\
\hline 18 & & 44.82 & 40.37 & 2.05 & 0.31 & 0.26 & 1.46 & 2.13 & 0.291 \\
\hline 19 & & 48.69 & 45.28 & 2.19 & 0.34 & 0.12 & 0.11 & 1.23 & 0.119 \\
\hline 20 & \multirow{7}{*}{$\begin{array}{l}\text { Black- } \\
\text { headed } \\
\text { gull }\end{array}$} & 39.18 & 34.04 & 2.55 & 0.36 & 0.63 & 0.47 & 2.11 & 0.305 \\
\hline 26 & & 43.97 & 39.92 & 2.33 & 0.86 & 0.20 & 0.09 & 2.80 & 0.212 \\
\hline 27 & & 45.36 & 40.88 & 2.83 & 0.91 & 0.22 & 0.06 & 1.98 & 0.200 \\
\hline 28 & & 44.10 & 40.00 & 2.80 & 0.96 & 0.21 & 0.09 & 1.85 & 0.243 \\
\hline 29 & & 46.69 & 41.72 & 1.84 & 0.48 & 0.15 & 0.05 & 1.64 & 0.169 \\
\hline 30 & & 35.09 & 31.43 & 2.38 & 0.42 & 0.56 & 0.31 & 1.57 & 0.201 \\
\hline 31 & & 25.71 & 24.05 & 1.39 & 0.23 & 0.23 & 0.52 & 0.74 & 0.211 \\
\hline 36 & $\begin{array}{c}\text { Common } \\
\text { Gull }\end{array}$ & 48.88 & 47.88 & 2.02 & 0.29 & 0.18 & 0.28 & 1.99 & 0.052 \\
\hline 21 & \multirow{5}{*}{$\begin{array}{l}\text { Great } \\
\text { crested } \\
\text { grebe }\end{array}$} & 42.39 & 38.25 & 2.00 & 0.55 & 0.10 & 0.15 & 3.94 & 0.060 \\
\hline 22 & & 37.47 & 33.18 & 2.67 & 0.52 & 0.43 & 0.56 & 6.42 & 0.436 \\
\hline 23 & & 39.46 & 34.81 & 2.00 & 0.52 & 0.24 & 0.23 & 3.79 & 0.147 \\
\hline 24 & & 41.41 & 37.11 & 1.83 & 0.62 & 0.17 & 0.11 & 1.91 & 0.111 \\
\hline 32 & & 39.55 & 36.69 & 1.97 & 0.29 & 0.25 & 0.15 & 1.08 & 0.149 \\
\hline 25 & $\begin{array}{c}\text { Common } \\
\text { tern }\end{array}$ & 46.87 & 42.52 & 1.28 & 0.22 & 0.15 & 0.68 & 1.85 & 0.185 \\
\hline 33 & \multirow[t]{5}{*}{ Black tern } & 42.49 & 40.49 & 2.83 & 1.32 & 0.13 & 0.07 & 2.96 & 0.089 \\
\hline 34 & & 44.78 & 42.40 & 2.74 & 1.07 & 0.11 & 0.04 & 2.54 & 0.073 \\
\hline 35 & & 42.46 & 40.52 & 2.82 & 1.20 & 0.16 & 0.07 & 2.88 & 0.089 \\
\hline 37 & & 44.43 & 41.49 & 2.62 & 1.05 & 0.13 & 0.05 & 2.67 & 0.072 \\
\hline 38 & & 41.90 & 40.57 & 3.04 & 1.36 & 0.16 & 0.08 & 3.38 & 0.092 \\
\hline
\end{tabular}


usually did not exceed $1 \%$ with the exception of the nests of common tern (1.05$1.36 \%$ d.w.) while magnesium content did not exceed $0.31 \%$ d.w. (Tab. 4).

The colonisation rate of the nests by keratinophilic fungi. The colonisation rate of the nests by keratinophilic fungi, measured as the number of colonised plates (samples) with the nest material, was high and ranged between $\sim 50 \%$ and $90 \%$ (Fig.1). Marsh harrier's nests were the least colonised nests (49\%) and nests of both tern species were the most colonised nests ( $90 \%$ ). Keratinophilic fungi also strongly colonised nests of three other bird species: grey heron, mute swan and great crested grebe $-84 \%-88 \%$. Although slightly lower, the colonisation rate of coot's nests and black-headed gull's nests was on a similar level and was $65 \%-70 \%$, respectively (Fig.1).

The richness and frequency of keratinophilic fungi. A total of 2193 isolates of fungi determined as geophilic dermatophytes or representatives of the Chrysosporium group were isolated from 390 samples (plates) with the nest material collected from 38 nests. Nine genera and 22 species, including nine species of geophilic dermatophytes and 13 species of the Chrysosporium group, were identified (Tab. 5). In keeping with the accepted rule that only one strain of a species can be present in one sample, 348 strains were identified as a representative community of 2193 isolates of keratinophilic fungi (Tab. 5).

The number of genera and species of keratinomycetes in the nests of individual bird species was not reflected in the colonisation rate of the nest material by these microorganisms (Tab. 5; Fig. 1). It was particularly evident in the case of black tern's nests (Chlidonia niger) in which only two genera and three species, including no dermatophytes, were recorded while the colonisation rate was very high $(90 \%)$. The highest number of species (and genera) were recorded in mute swan's nests and coot's nests: 11 and 10 (5 and 7), respectively.

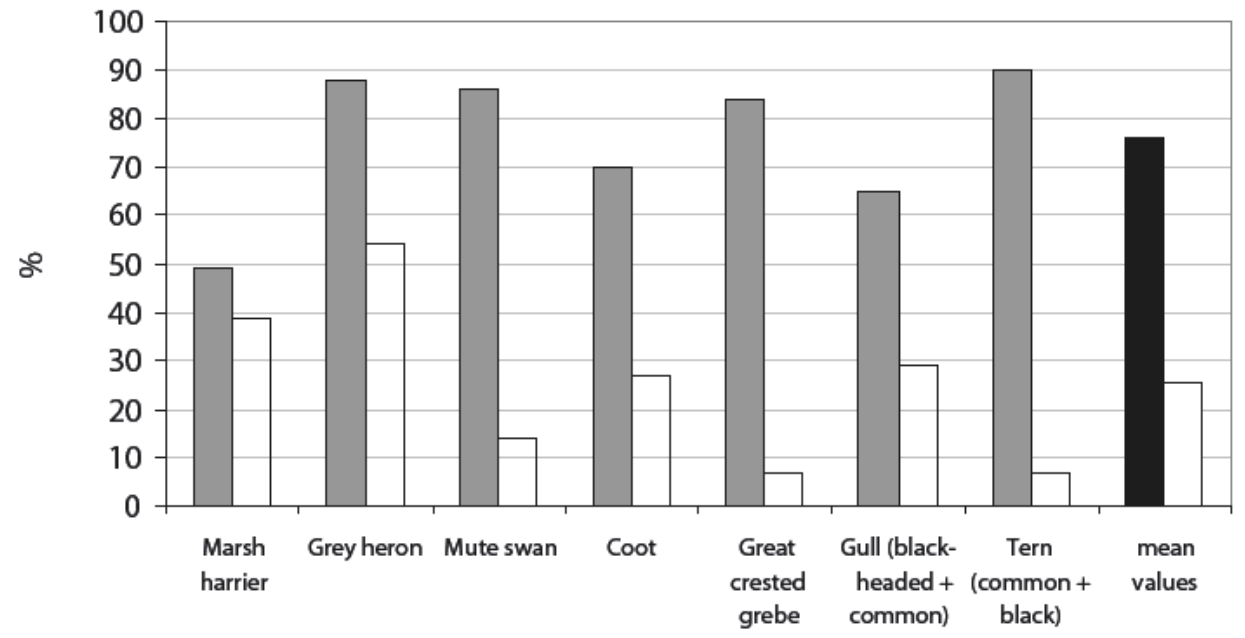

keratinophilic fungi $\square$ non-keratinophilic fungi

Fig.1. The colonisation rate (in \%) of the nests by keratinophilic and non-keratinophilic fungi. 
Table 5

Numbers of isolated genera, species and isolated of geophilic dermatophytes (GD) and the Chrysosporium group (Ch)

\begin{tabular}{|c|l|c|c|c|c|c|c|c|c|c|c|}
\hline No & \multicolumn{1}{|c|}{ Bird species } & \multicolumn{3}{|c|}{ Genus } & \multicolumn{3}{|c|}{ Species } & \multicolumn{3}{c|}{ Strain } & $\begin{array}{c}\text { Total } \\
\text { number } \\
\text { of isolates }\end{array}$ \\
\cline { 3 - 15 } & & Total & GD & Ch & Total & GD & Ch & Total & GD & Ch \\
\hline 1 & Marsh harrier & 4 & 2 & 2 & 7 & 2 & 5 & 26 & 6 & 20 & 92 \\
\hline 2 & Grey heron & 4 & 2 & 2 & 6 & 2 & 5 & 66 & 25 & 41 & 122 \\
\hline 3 & Mute swan & 5 & 4 & 1 & 11 & 4 & 7 & 61 & 27 & 34 & 483 \\
\hline 4 & Coot & 7 & 2 & 5 & 10 & 4 & 6 & 52 & 9 & 43 & 282 \\
\hline 5 & Great crested grebe & 4 & 2 & 2 & 5 & 2 & 3 & 41 & 4 & 37 & 366 \\
\hline 6 & Black-headed gull & 3 & 1 & 2 & 5 & 1 & 4 & 49 & 4 & 45 & 376 \\
\hline 7 & Common gull & & & & & & & & & & \\
\hline 8 & Common tern & 2 & 0 & 2 & 3 & 0 & 3 & 53 & 0 & 53 & 472 \\
\hline 9 & Black tern & 9 & 4 & 5 & 22 & 9 & 13 & 348 & 75 & 273 & 2193 \\
\hline \multicolumn{2}{|l}{ Isolated in total } & & & & & & & \\
\hline
\end{tabular}

The data given in Tab. 5 shows that non-dermatophytic fungi representing the Chrysosporium group were the dominant group. A total of 273 strains were recorded, which corresponded to $78 \%$ of all keratinomycetes identified in the study. The remainder (22\%) of the community of keratinophilic fungi was represented by geophilic dermatophytes (75 strains).

Generic and species diversity of keratinophilic fungi. Of the nine genera isolated from the nests, four (Microsporum, Trichophyton and their teleomorphs Nannizzia and Arthroderma) represented geophilic dermatophytes and five represented non-dermatophytic fungi: Chrysosporium and Myceliophthora together with teleomorphs Arthroderma, Aphanoascus and Ctenomyces (Tabs 6-8, Fig. 2). The genus

Table 6

A list of geophilic dermatophytes and Chrysosporium isolated from the nests of wetland birds

\begin{tabular}{|c|c|c|c|}
\hline No & Species of fungus & Anamorph & Teleomorph \\
\hline 1 & Aphanoascus fulvescens (Cooke) Apinis & - & + \\
\hline 2 & Arthroderma cifferii Varsavsky et Ajello & - & + \\
\hline 3 & A. cuniculi Dawson & - & + \\
\hline 4 & A. curreyi Berk. & - & + \\
\hline 5 & A. insingulare Padhye et Carm. & - & + \\
\hline 6 & A. quadrifidum Dawson et Gentles & - & + \\
\hline 7 & A. uncinatum Dawson et Gentles & - & + \\
\hline 8 & Chrysosporium keratinophilum Frey ex Carm. & + & - \\
\hline 9 & Ch. pannicola (Corda) van Oorschot et Stalpers & + & - \\
\hline 10 & Ch. quenslandicum Apinis et Rees & + & - \\
\hline 11 & Ch. tropicum Carm. & + & - \\
\hline 12 & Myceliophthora an. Arthroderma tuberculatum Kuehn & + & - \\
\hline 13 & Chrysosporium an. A. curreyi Berk. & + & - \\
\hline 14 & Chrysosporium an. Renispora flavissima Sigler et al. & + & - \\
\hline 15 & Ctenomyces serratus Eidam & - & + \\
\hline 16 & Microsporum cookei Ajello & + & - \\
\hline 17 & M. fulvum Uriburu & + & - \\
\hline 18 & M. gypseum (Bodin) Guiart et Grigoriakis & + & - \\
\hline 19 & Myceliophthora an. Ct. serratus & - & + \\
\hline 20 & Nannizzia gypsea (Nannizzi) Stockdale & - & + \\
\hline 21 & Trichophyton ajelloi (Vanbr.) Ajello & + & - \\
\hline 22 & T. terrestre Durie et Frey & + & - \\
\hline
\end{tabular}

Abbreviations: (+) yes; (-) no 


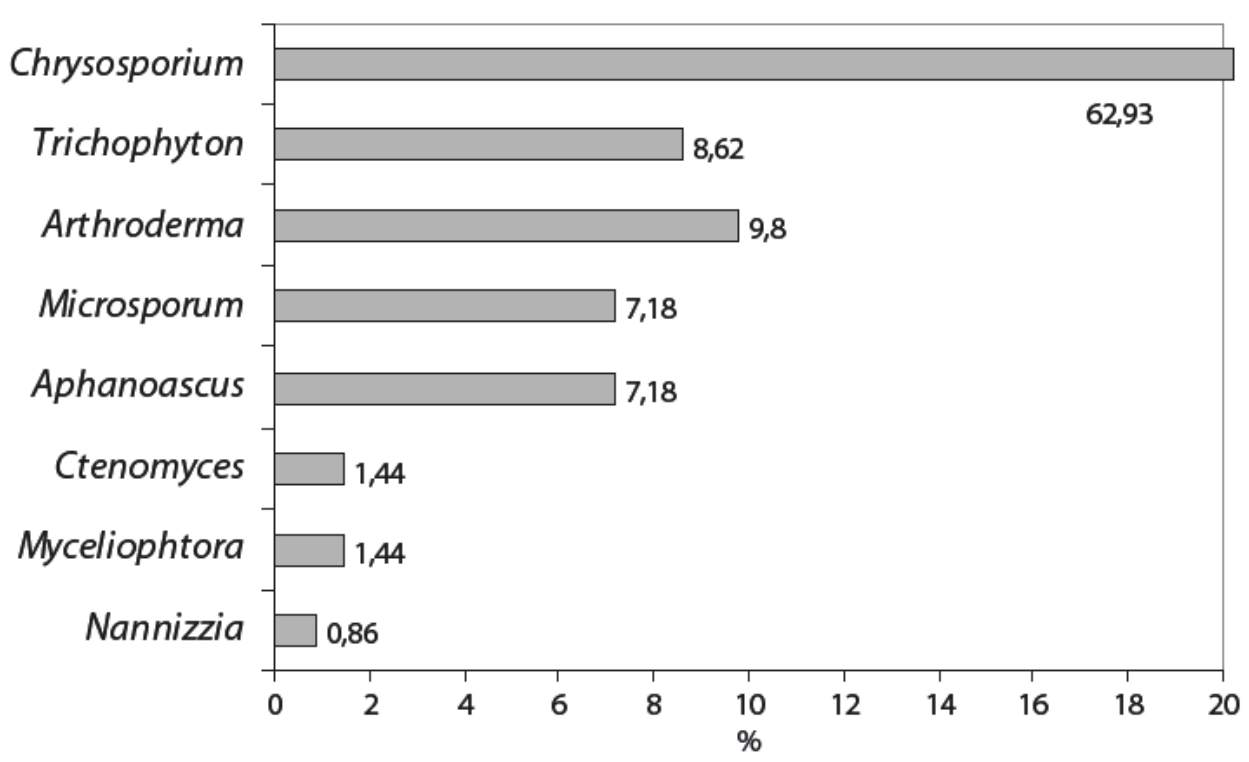

Fig. 2. The share of individual fungal genera in the community of keratinophilic fungi.

Chrysosporium, which represented ca. $63 \%$ of all keratinophilic fungi isolated in the analysis, dominated (219 strains). Trichophyton (8.6\% of all keratinomycetes) and Microsporum $(7.2 \%)$ were the most frequently recorded genera within geophilic dermatophytes. The lowest share of keratinophilic fungi was observed for the genus Nannizzia (0.86\%) (Fig. 2).

The analysis of the species composition of geophilic dermatophytes showed that Trichophyton terrestre together with the teleomorphs: Arthroderma quadrifidum and A. insingulare, had the highest share, constituting $12.5 \%$ of all keratinophilic fungi isolated in the study. Microsporum gypseum together with its teleomorph was recorded less frequently (7.1\%). Other dermatophyte species: Microsporum cookei, $M$. fulvum, Trichophyton ajelloi and its teleomorph Arthroderma uncinatum, occurred rarely or sporadically (Tab. 7).

Chrysosporium keratinophilum, which together with its teleomorph Aphanoascus fulvescens constituted $53 \%$ of total keratinomycetes of the nests (a total of 184 strains), was the most frequently isolated species in the Chrysosporium group (Tab. 8). Other species of this group were either rare or sporadic with the exception of Ch. tropicum ( $11.5 \%$ of total keratinomycetes).

Simpson's index was calculated to assess the species diversity of keratinophilic fungi colonising the nests (Tab. 9). Both the number and the frequency of fungal species were included in the assessment. The assessment showed that the lowest total Simpson's index (D) indicative of a low species diversity was observed for communities of keratinophilic fungi of the nests of terns $(D=0.1400)$ and gulls $(D=0.3900)$. A high species diversity of the biota of these fungi was observed in the nests of mute swans and coots $(D=0.8400$ and 0.8300$)$. A slightly lower species diversity $(D=0.8018)$ was also observed for communities of keratinomycetes occurring in marsh harrier's nests although the colonisation rate by these fungi was the lowest (Tab. 9, Fig. 1). 
Table 7

The frequency and distribution of individual species of geophilic dermatophytes in the nests of wetland birds

\begin{tabular}{|c|c|c|c|c|c|c|c|c|c|c|c|}
\hline \multirow{2}{*}{$\begin{array}{c}\text { Nest } \\
\text { number }\end{array}$} & \multirow[b]{2}{*}{$\begin{array}{l}\text { Bird } \\
\text { species }\end{array}$} & \multicolumn{9}{|c|}{ Fungal species } & \multirow[b]{2}{*}{ Tota } \\
\hline & & A.i. & A. q. & A. u. & $\begin{array}{l}\text { M. } \\
\text { c. }\end{array}$ & M. f. & M. & N.g. & T. a. & T. t. & \\
\hline 1 & \multirow{3}{*}{$\begin{array}{l}\text { Marsh } \\
\text { harrier }\end{array}$} & - & - & - & - & - & - & - & - & - & 0 \\
\hline 2 & & - & - & - & - & - & - & - & - & - & 0 \\
\hline 3 & & 4* & - & - & - & - & - & - & - & 2 & 6 \\
\hline 4 & \multirow{6}{*}{$\begin{array}{l}\text { Grey } \\
\text { heron }\end{array}$} & - & - & - & - & - & - & - & - & 7 & 11 \\
\hline 5 & & - & - & - & - & - & - & - & - & - & 0 \\
\hline 6 & & - & - & - & - & - & - & - & - & - & 0 \\
\hline 7 & & - & - & - & - & - & - & - & - & - & 0 \\
\hline 8 & & - & 5 & - & - & - & - & - & - & 7 & 12 \\
\hline 9 & & - & - & - & - & - & - & - & - & 6 & 6 \\
\hline 10 & \multirow[t]{5}{*}{ Mute swan } & - & - & - & - & - & - & - & - & - & 0 \\
\hline 11 & & - & - & - & - & - & 1 & - & - & 4 & 5 \\
\hline 12 & & 1 & - & - & - & - & - & - & - & 1 & 2 \\
\hline 13 & & - & - & - & - & - & 7 & 3 & - & - & 10 \\
\hline 14 & & - & - & - & - & - & 10 & - & - & - & 10 \\
\hline 15 & \multirow[t]{5}{*}{ Coot } & - & - & - & 2 & 1 & 3 & - & - & - & 6 \\
\hline 16 & & - & - & - & - & - & - & - & - & 1 & 1 \\
\hline 17 & & - & - & - & - & - & 1 & - & - & 1 & 2 \\
\hline 18 & & - & - & - & - & - & - & - & - & - & 0 \\
\hline 19 & & - & - & - & - & - & - & - & - & - & 0 \\
\hline 20 & \multirow{7}{*}{$\begin{array}{l}\text { Black- } \\
\text { headed } \\
\text { Gull }\end{array}$} & - & - & - & - & - & - & - & - & 4 & 4 \\
\hline 26 & & - & - & - & - & - & - & - & - & - & 0 \\
\hline 27 & & - & - & - & - & - & - & - & - & - & 0 \\
\hline 28 & & - & - & - & - & - & - & - & - & - & 0 \\
\hline 29 & & - & - & - & - & - & - & - & - & - & 0 \\
\hline 30 & & - & - & - & - & - & - & - & - & - & 0 \\
\hline 31 & & - & - & - & - & - & - & - & - & - & 0 \\
\hline 36 & $\begin{array}{l}\text { Common } \\
\text { gull }\end{array}$ & - & - & - & - & - & - & - & - & - & 0 \\
\hline 21 & \multirow{5}{*}{$\begin{array}{l}\text { Great } \\
\text { crested } \\
\text { grebe }\end{array}$} & - & - & - & - & - & - & - & - & - & 0 \\
\hline 22 & & - & - & 3 & - & - & - & - & - & - & 3 \\
\hline 23 & & - & - & - & - & - & - & - & 1 & - & 1 \\
\hline 24 & & - & - & - & - & - & - & - & - & - & 0 \\
\hline 32 & & - & - & - & - & - & - & - & - & - & 0 \\
\hline 25 & $\begin{array}{l}\text { Common } \\
\text { tern }\end{array}$ & - & - & - & - & - & - & - & - & - & 0 \\
\hline 33 & \multirow{6}{*}{ Black tern } & - & - & - & - & - & - & - & - & - & 0 \\
\hline 34 & & - & - & - & - & - & - & - & - & - & 0 \\
\hline 35 & & - & - & - & - & - & - & - & - & - & 0 \\
\hline 37 & & - & - & - & - & - & - & - & - & - & 0 \\
\hline 38 & & - & - & - & - & - & - & - & - & - & 0 \\
\hline In total & & 5 & 5 & 3 & 2 & 1 & 22 & 3 & 1 & 33 & 75 \\
\hline
\end{tabular}

Abbreviations: A.i. - Arthroderma insingulare; A.q. - A. quadrifidum; A.u. - A. uncinatum; M.c. - Microsporum cookei; M.f. - M. fulvum; M.g. - M. gypseum (complex); N.g. - Nannizzia gypsea; T.a. - Trichophyton ajelloi; T.t. - T. terrestre (complex); * - number of strains

The distribution of keratinophilic fungi and nest properties. Data on the occurrence of individual species of geophilic dermatophytes and Chrysosporium in each of the 38 nests are presented in Tables 7 and 8. They show a non-uniform distribution of the populations of keratinophilic fungi in the microhabitat: their occurrence was observed in some nests while they were absent in others. This corresponded to 
Table 8

The frequency and distribution of species of the Chrysosporium group in the nests of wetland birds

\begin{tabular}{|c|c|c|c|c|c|c|c|c|c|c|c|c|c|c|c|c|}
\hline \multirow{2}{*}{\begin{tabular}{|c|} 
Nest \\
number
\end{tabular}} & \multirow{2}{*}{ Bird species } & \multicolumn{14}{|c|}{ Fungal species } & \multirow[b]{2}{*}{ Total } \\
\hline & & A.f. & $\begin{array}{l}\text { A. } \\
\text { cif. }\end{array}$ & $\begin{array}{l}\text { A. } \\
\text { cun. }\end{array}$ & $\begin{array}{l}\text { A. } \\
\text { cur. }\end{array}$ & $\begin{array}{l}\text { Ch. } \\
\text { k. }\end{array}$ & $\begin{array}{l}\text { Ch. } \\
\text { p. }\end{array}$ & $\begin{array}{l}\text { Ch. } \\
\text { q. }\end{array}$ & $\begin{array}{l}\text { Ch. } \\
\text { trop. }\end{array}$ & $\begin{array}{l}\text { Ch. } \\
\text { tub. }\end{array}$ & $\begin{array}{l}\text { Ch. } \\
\text { cur. }\end{array}$ & $\begin{array}{l}\text { Ch. } \\
\text { fl. }\end{array}$ & $\begin{array}{l}\text { Ch. } \\
\text { sp. }\end{array}$ & $\begin{array}{l}\text { M. } \\
\text { ser. }\end{array}$ & $\begin{array}{l}\text { C. } \\
\text { ser. }\end{array}$ & \\
\hline 1 & \multirow{3}{*}{$\begin{array}{l}\text { Marsh } \\
\text { harrier }\end{array}$} & $6^{*}$ & - & - & - & 8 & - & - & - & - & - & 3 & - & - & - & 17 \\
\hline 2 & & - & - & - & - & - & - & - & - & - & - & - & - & - & - & 0 \\
\hline 3 & & - & - & - & - & - & - & 2 & 1 & - & - & - & - & - & - & 3 \\
\hline 4 & \multirow{6}{*}{$\begin{array}{l}\text { Grey } \\
\text { heron }\end{array}$} & - & - & - & - & 5 & - & - & 7 & - & 1 & - & - & - & 1 & 14 \\
\hline 5 & & - & - & - & - & - & - & - & 10 & - & - & - & - & - & - & 10 \\
\hline 6 & & - & - & - & - & 4 & - & - & 5 & - & - & - & - & - & - & 9 \\
\hline 7 & & - & - & - & - & - & - & - & 4 & - & - & - & - & - & - & 4 \\
\hline 8 & & - & - & - & - & - & - & - & 1 & - & - & - & - & - & - & 1 \\
\hline 9 & & - & - & - & - & 2 & - & - & 1 & - & - & - & - & - & - & 3 \\
\hline 10 & \multirow{5}{*}{$\begin{array}{l}\text { Mute } \\
\text { swan }\end{array}$} & - & - & 2 & 1 & 1 & 3 & - & 3 & - & - & - & - & - & - & 10 \\
\hline 11 & & - & - & - & - & 1 & - & - & - & - & - & - & - & - & - & 1 \\
\hline 12 & & - & 5 & - & - & 3 & - & 5 & 1 & - & - & - & - & - & - & 14 \\
\hline 13 & & - & - & - & - & 4 & - & - & - & - & - & - & - & - & - & 4 \\
\hline 14 & & - & 4 & - & - & 1 & - & - & - & - & - & - & - & - & - & 5 \\
\hline 15 & \multirow[t]{5}{*}{ Coot } & 3 & - & - & 1 & 3 & - & - & - & - & - & - & - & - & - & 7 \\
\hline 16 & & 4 & - & - & - & 7 & - & - & - & - & - & - & - & - & - & 11 \\
\hline 17 & & 2 & - & - & 4 & 2 & 1 & - & - & - & - & - & 1 & - & - & 10 \\
\hline 18 & & 4 & - & - & - & 1 & 1 & - & - & - & - & - & - & 3 & 3 & 12 \\
\hline 19 & & 1 & - & - & - & - & - & - & - & - & - & - & - & 2 & - & 3 \\
\hline 20 & \multirow{7}{*}{$\begin{array}{l}\text { Black- } \\
\text { headed } \\
\text { gull }\end{array}$} & - & - & - & - & - & 2 & - & 1 & - & - & - & 1 & - & - & 4 \\
\hline 26 & & - & - & - & - & 8 & - & - & - & - & - & - & - & - & - & 8 \\
\hline 27 & & 2 & - & - & - & 5 & 1 & - & - & - & - & - & - & - & - & 6 \\
\hline 28 & & - & - & - & - & 5 & - & - & - & - & - & - & - & - & - & 5 \\
\hline 29 & & - & - & - & - & - & - & - & - & - & - & - & - & - & - & 0 \\
\hline 30 & & - & - & - & - & 10 & - & - & - & - & - & - & - & - & - & 10 \\
\hline 31 & & - & - & - & - & - & - & - & - & - & - & - & - & - & - & 0 \\
\hline 36 & $\begin{array}{l}\text { Common } \\
\text { Gull }\end{array}$ & - & - & - & - & 10 & - & - & - & - & - & - & - & - & - & 10 \\
\hline 21 & \multirow{5}{*}{$\begin{array}{l}\text { Great } \\
\text { Crested } \\
\text { Grebe }\end{array}$} & - & - & - & - & 10 & - & - & - & - & - & - & - & - & - & 10 \\
\hline 22 & & - & - & - & - & 9 & - & - & - & - & - & - & - & - & 1 & 9 \\
\hline 23 & & - & - & - & - & 2 & - & - & 2 & - & - & - & - & - & - & 4 \\
\hline 24 & & - & - & - & - & 2 & - & - & 4 & - & - & - & - & - & - & 6 \\
\hline 32 & & - & - & - & - & 7 & - & - & - & - & - & - & - & - & - & 7 \\
\hline 25 & $\begin{array}{l}\text { Common } \\
\text { tern }\end{array}$ & - & - & - & - & 8 & - & - & - & 1 & - & - & - & - & - & 9 \\
\hline 33 & \multirow{5}{*}{$\begin{array}{l}\text { Black } \\
\text { tern }\end{array}$} & - & - & - & - & 8 & - & - & - & - & - & - & - & - & - & 8 \\
\hline 34 & & - & - & - & - & 7 & - & - & - & - & - & - & - & - & - & 7 \\
\hline 35 & & - & - & - & - & 7 & - & - & - & - & - & - & - & - & - & 7 \\
\hline 37 & & 3 & - & - & - & 10 & - & - & - & - & - & - & - & - & - & 10 \\
\hline 38 & & - & - & - & - & 9 & - & - & - & - & - & - & - & - & - & 9 \\
\hline \multicolumn{2}{|c|}{ In total } & 25 & 9 & 2 & 6 & 159 & 8 & 7 & 40 & 1 & 1 & 3 & 2 & 5 & 5 & 273 \\
\hline
\end{tabular}

Abbreviations: A.f. - Aphanoascus fulvescens; A.cif. - Arthroderma cifferii; A.cun. - A. cuniculi; A.cur. - A. curreyi; Ch.k .- Chrysosporium keratinophilum; Ch.p. - Ch. pannicola; Ch.q. - Ch. queenslandicum; Ch.trop. - Ch. tropicum; Ch.tub. - Ch. tuberculatum; Ch. cur. - Ch. curreyi an Arthoderma curreyi; Ch.fl. - Chrysosporium an. Renispora flavissima; Ch.sp.-Chrysosporium sp.; M.ser. - Myceliophthora an. Ctenomyces serratus; C.ser. - Ctenomyces serratus; ${ }^{*}$ - number of strains

different physical and chemical properties of the nests, primarily the humidity level and $\mathrm{pH}$. In the group of geophilic dermatophytes, Trichophyton terrestre together with the perfect stages: Arthroderma insingulare and A. quadrifidum, mostly colonised the nests of grey herons and single nests of marsh harriers and black-headed gulls (Tab. 7). Their humidity was lower than that observed in other nests (Tab. 3) and ranged 
Table 9

Simpson's index of species diversity (D) for communities of keratinophilic fungi in the nests

\begin{tabular}{|c|l|c|}
\hline No & \multicolumn{1}{|c|}{ Bird species } & Simpson's index \\
\hline 1 & Marsh harrier & 0.8018 \\
\hline 2 & Grey heron & 0.6942 \\
\hline 3 & Mute swan & 0.8400 \\
\hline 4 & Coot & 0.8300 \\
\hline 5 & Great crested grebe & 0.4400 \\
\hline 6 & Gull (black-headed + common) & 0.3900 \\
\hline 7 & Tern (common + black) & 0.1400 \\
\hline
\end{tabular}

from $18.78 \%$ to $62.30 \%$, and their $\mathrm{pH}$ was alkaline ( $\mathrm{pH}$ in $\mathrm{H}_{2} \mathrm{O}$ 7.32-7.76). Another dermatophyte species recorded more frequently, Microsporum gypseum together with the teleomorph Nannizzia gypsea, colonised only nests of mute swans (three of the five studied) and coots (two of the three studied). These nests had a neutral $\mathrm{pH}$ : $\mathrm{pH}$ in $\mathrm{H}_{2} \mathrm{O}$ 6.55-7.10 (Tab. 3).

The most numerous species within both communities of keratinophilic fungi, Chrysosporium keratinophilum together with its teleomorph Aphanoascus fulvescens, showed preferences for habitats characterised by a very high humidity, which was recorded in the case of coot's nests, great crested grebe's nests as well as the nests of both species of gulls and terns (Tab. 8). Apart from the above species, Chrysosporium tropicum, one of more frequent species, mostly colonised grey heron's nests while its occurred rarely or sporadically or did not occur at all in others (Tab. 8).

It was shown that the frequency of $T$. terrestre (together with the teleomorph) is negatively correlated with the nest's humidity level and that of Ch. keratinophilum is positively correlated with it. An even stronger and positive correlation was observed between the frequency of occurrence of T. terrestre and the nest's $\mathrm{pH}$ and phosphorus content. The frequency of both species: Ch. keratinophilum (together with the teleomorph) and T. terrestre (together with the teleomorph), was also significantly positively correlated with the calcium content in the nests although the correlation coefficients were lower than those for $\mathrm{pH}$ and phosphorus content (Tab. 10).

The colonisation rate of the nests and the species composition of so-called nonkeratinophilic fungi growing on feathers. The colonisation rate of the nest material by ubiquistic fungi (polyphages), arbitrarily called non-keratinophilic, varied greatly and ranged from $12 \%$ to $95 \%$. The greatest number of ubiquistic fungi able

Table 10

Correlation coefficients between the frequency of selected species of keratinophilic fungi (together with the teleomorph) and some physical and chemical properties of the nest material $(\mathrm{p}=0.05)$

\begin{tabular}{|c|l|c|c|c|}
\hline No & \multicolumn{1}{|c|}{ Property } & $\begin{array}{c}\text { Chrysosporium } \\
\text { keratinophilum } \\
\text { teleomorph }\end{array}$ & $\begin{array}{c}\text { Trichophyton terrestre } \\
+ \text { teleomorph }\end{array}$ & $\begin{array}{c}\text { Microsporum } \\
\text { gypseum }+ \\
\text { teleomorph }\end{array}$ \\
\hline 1 & Humidity & 0.62 & -0.61 & 0.28 \\
\hline 2 & pH $\mathrm{H}_{2} \mathrm{O}$ & -0.28 & 0.81 & -0.41 \\
\hline 3 & Total nitrogen content & 0.324 & 0.819 & -0.37 \\
\hline 4 & Phosphorus content & 0.08 & 0.97 & -0.22 \\
\hline 5 & Calcium content & 0.63 & 0.54 & 0.03 \\
\hline
\end{tabular}


Table11

A list of non-keratinophilic fungi isolated from the nests of wetland birds with the keratin baiting method

\begin{tabular}{|c|c|c|c|c|c|c|c|c|c|c|c|}
\hline No & Fungal species & 1 & 2 & 3 & 4 & 5 & 6 & 7 & 8 & 9 & Total \\
\hline 1 & $\begin{array}{l}\text { Acremonium chrysogenum } \\
\text { (Thirum and Sukap) W. } \\
\text { Gams }\end{array}$ & - & - & - & $5^{*}$ & - & - & - & - & - & 5 \\
\hline 2 & A. rutilum W.Gams & - & - & - & - & 1 & - & - & - & - & 1 \\
\hline 3 & Acremonium sp. & 1 & - & - & - & - & - & - & - & - & 1 \\
\hline 4 & $\begin{array}{l}\text { Alternaria alternata (Fr.) } \\
\text { Keissler }\end{array}$ & 4 & - & - & 1 & - & - & - & - & - & 5 \\
\hline 5 & $\begin{array}{l}\text { Aspergillus flavus Link ex } \\
\text { Gray }\end{array}$ & - & 5 & - & - & - & - & - & - & - & 5 \\
\hline 6 & A. fumigatus Fres. & 7 & 9 & 2 & 1 & 4 & 3 & - & 2 & 1 & 29 \\
\hline 7 & A. niger van Tieghem & - & 1 & - & - & - & - & - & - & - & 1 \\
\hline 8 & Candida sp. & - & 1 & - & - & - & - & - & - & - & 1 \\
\hline 9 & $\begin{array}{l}\text { Chaetomium globosum } \\
\text { Kunze ex Fr. }\end{array}$ & - & - & 10 & - & - & - & - & - & - & 10 \\
\hline 10 & $\begin{array}{l}\text { Doratomyces microsporus } \\
\text { (Sacc.) Morton \& G.Sm. }\end{array}$ & 6 & 1 & - & - & - & - & - & - & - & 7 \\
\hline 11 & $\begin{array}{l}\text { D. nanus (Ehrenb. Ex Link) } \\
\text { Morton \& Smith }\end{array}$ & - & 1 & - & - & - & - & - & - & - & 1 \\
\hline 12 & $\begin{array}{l}\text { Fusarium culmorum } \\
\text { (Schwabe) Snyd. Et Hansen }\end{array}$ & - & - & - & 1 & - & - & - & - & - & 1 \\
\hline 13 & $\begin{array}{l}\text { F. equiseti (Corda) Sacc. } \\
\text { Gordon }\end{array}$ & - & - & - & 1 & - & - & - & - & - & 1 \\
\hline 14 & F. solani (Mart.) Sacc. & - & - & - & 1 & - & - & - & - & - & 1 \\
\hline 15 & $\begin{array}{l}\text { Geotrichum candidum Link } \\
\text { ex Leman }\end{array}$ & - & 1 & - & - & - & - & - & - & - & 1 \\
\hline 16 & Geotrichum sp. & 1 & 1 & - & - & - & - & - & - & - & 2 \\
\hline 17 & $\begin{array}{l}\text { Gliocladium catenulatum } \\
\text { Gilm. \& Abbott }\end{array}$ & - & - & 1 & 2 & - & 10 & - & - & - & 13 \\
\hline 18 & G. roseum Bain. & - & - & - & 1 & 1 & - & - & - & - & 2 \\
\hline 19 & $\begin{array}{l}\text { Mariannea elegans (Corda) } \\
\text { Samson }\end{array}$ & 2 & - & - & - & - & - & - & - & - & 2 \\
\hline 20 & $\begin{array}{l}\text { Monocillium indicum } \\
\text { Saksena }\end{array}$ & - & 1 & - & - & - & - & - & - & - & 1 \\
\hline 21 & $\begin{array}{l}\text { Paeciliomyces farinosus } \\
\text { (Holm ex Gray) A.H.S. } \\
\text { Brown \& G. Sm. }\end{array}$ & - & 1 & - & - & - & - & - & - & - & 1 \\
\hline 22 & P. lilacinus (Thom) Samson & - & 1 & - & - & 1 & 1 & - & - & - & 3 \\
\hline 23 & P. variotii Bain. & 1 & - & - & - & - & - & - & - & - & 1 \\
\hline 24 & Papulaspora immersa Hotson & - & 1 & - & - & - & - & - & - & - & 1 \\
\hline 25 & $\begin{array}{l}\text { Penicillium chrysogenum } \\
\text { Thom }\end{array}$ & - & 2 & - & - & - & - & - & - & - & 2 \\
\hline 26 & P. expansum Link ex Gray & - & 1 & - & 1 & - & - & - & 1 & - & 3 \\
\hline 27 & P. purpurogenum Stoll & - & - & - & - & - & 4 & - & - & 2 & 6 \\
\hline 28 & P. verrucosum Dierckx & - & 5 & - & - & - & - & - & - & 2 & 7 \\
\hline 29 & Penicillium sp. & - & - & - & 1 & 3 & 1 & - & - & - & 5 \\
\hline 30 & $\begin{array}{l}\text { Scedosporum apiospermum } \\
\text { (Sacc.) Sacc. Ex Castell \& } \\
\text { Chalmes }\end{array}$ & - & - & - & - & 1 & - & - & - & - & 1 \\
\hline 31 & $\begin{array}{l}\text { Scopulariopsis acremonium } \\
\text { Delacr. Vuill. }\end{array}$ & - & 1 & - & - & - & - & - & - & - & 1 \\
\hline 32 & S. brevicaulis (Sacc.) Bain. & 6 & 10 & 2 & 1 & 1 & 6 & - & 1 & - & 27 \\
\hline 33 & $\begin{array}{l}\text { Torula herbarum Pers. Ex } \\
\text { Gray }\end{array}$ & 1 & - & - & - & - & - & - & - & - & 1 \\
\hline 34 & $\begin{array}{l}\text { Trichoderma viride Pers. Ex } \\
\text { Gray }\end{array}$ & - & 1 & 1 & 3 & 1 & - & - & - & - & 6 \\
\hline 35 & $\begin{array}{l}\text { Trichothecium reseum (Pers.) } \\
\text { Link ex Gray }\end{array}$ & 1 & - & - & - & - & - & - & - & - & 1 \\
\hline 36 & $\begin{array}{l}\text { Verticillium chlamydosporum } \\
\text { Goddard }\end{array}$ & - & 1 & - & - & - & - & - & - & - & 1 \\
\hline
\end{tabular}




\begin{tabular}{|c|l|c|c|c|c|c|c|c|c|c|c|}
\hline 37 & V. lecani (Zimm.) Viegas & 3 & 1 & - & 5 & - & 9 & - & 1 & - & 19 \\
\hline 38 & V.psalliotae Terschow & 4 & 4 & - & 1 & - & 1 & - & - & - & 10 \\
\hline 39 & Verticillium sp. & - & - & - & 2 & - & - & - & - & - & 2 \\
\hline 40 & yeasts & 2 & - & - & - & 1 & - & - & 1 & - & 4 \\
\hline & Total & 39 & 50 & 16 & 27 & 14 & 35 & 0 & 6 & 5 & 192 \\
\hline
\end{tabular}

Abbreviations: 1 - Marsh harrier; 2 - Grey heron; 3 - Mute swan; 4 - Coot; 5 - Great crested grebe; 6 Black-headed gull; 7 - Common gull; 8 - Common tern; 9 - Black tern; ( )* - number of strains

to colonise feathers occurred in the nests of grey herons and marsh harriers, and the smallest number was recorded in the nests of great crested grebes and mute swans (Fig. 1).

Unlike keratinophilic fungi, the colonisation rate of native keratin by ubiquistic fungi corresponded to the richness and frequency of their species (Fig. 1, Tab. 11). The greatest richness and species diversity was observed in the case of non-keratinophilic fungi colonising the nests of grey herons and marsh harriers: 19 and 11 species and 50 and 39 strains, respectively (Tab. 11). The smallest species differentiation of the biota of ubiquistic species colonising feathers was observed in the nests of both tern species: common tern and black tern, 5 and 3, respectively, represented by single strains (Tab. 11).

As regards the species composition, ubiquistic fungi recorded in the nests and colonising native feathers were represented by 34 species belonging to 20 genera (the species of ten isolates was not determined). The most frequently isolated genera were Aspergillus, Gliocladium, Paeciliomyces, Penicillium and Scopulariopsis (Tab. 11). Similarly to keratinophilic species, individual species of non-keratinophilic fungi showed preferences for nests of specific bird species. Scopulariopsis brevicaulis was most frequently isolated from the nests of grey herons and marsh harriers: $15 \%$ and $20 \%$, respectively, and Aspergillus fumigatus: an 18\%-share within nonkeratinophilic fungi colonising these nests. Additionally, Doratomyces microsporus was frequently isolated from marsh harrier's nests on feathers (15\% respectively). Among other ubiquistic species, two polyphagous species: Gliocladium catenulatum and Verticillium lecani, occurred as co-dominant species in black-headed gull's nests: the colonisation rate of feathers was $28 \%$ and $25 \%$, respectively. On the other hand, Chaetomium globosum, which represented ca. $63 \%$ of total non-keratinophilic fungi, was an accompanying species of feather colonisation by typically keratinophilic fungi in mute swan's nests (Tab. 11).

\section{DISCUSSION}

The present study shows that keratinophilic fungi colonised $86.8 \%$ of the nests of wetland birds. A slightly higher (ca. 5\%) occurrence frequency of keratinomycetes was recorded only in nest boxes (Hubalek et al. 1973). The occurrence frequency of keratinophilic fungi, however, was higher in comparison with open-cup nests of land fungi. Hubalek et al. (1973) demonstrated the presence of keratinophilic fungi in $72.7 \%$ of such nests, mostly belonging to Passeriformes. 
The investigations also showed a high ( $76 \%$ on average) colonisation rate of the nest material by keratinophilic fungi. The nest material of marsh harriers $(49 \%)$ was the least colonised and that of both tern species $(90 \%)$ was the most strongly colonised material.

The widespread distribution of keratinophilic fungi in the nests of wetland birds was conditioned by the presence of the birds (breeding) and keratin matter, mostly feathers and less frequently hair, animal food remains, excrements and pellets. A considerable accumulation of total nitrogen as well as phosphorus and calcium indicated nest contamination with remains of animal origin. Both the nutrient factor (keratin) and high humidity as well as neutral to alkaline $\mathrm{pH}(\mathrm{pH}$ 6.5-7.8) of the nest material were favourable for the development of keratinophilic fungi in the nests (Tab. 2). As previous investigations show (Korniłłowicz-Kowalska 1997), keratinophilic fungi grow well on surfaces of feathers which are a non-wettable substrate when such substrate is in contact with water. The process is intensive when the substrate's pH ranges between 6.5 and 7.8 (Korniłłowicz-Kowalska, Bohacz 2002), which is connected with the optimum of extracellular keratinolytic proteases of these fungi (Korniłłowicz-Kowalska 1999). Similar observations were made by Kunert (2000) in relation to biodegradation of hair by keratinolytic fungi.

On the whole, a high richness of kertinomycete species was observed in the nests of wetland birds examined: altogether 22 species belonging to nine genera were recorded. A total of no more than 15 species of keratinomycetes is regularly isolated from natural environments such as the soil (Gueho, Villard and Guinet 1985; Korniłłowicz-Kowalska, Bohacz 2002). However, a high differentiation of the composition and the frequency of keratinomycete species colonising the nests was observed in the investigations depending on the species of the nesting bird. The greatest number of fungal species and their diversity, was observed in the nests of mute swans and coots and, further, of march harriers and grey herons. The smallest number of species and the lowest Simpson's indices were recorded in the nests of both tern species and black-headed gulls. Great differences in the species composition of keratinophilic fungi in nests depending on the bird's species were previously demonstrated by Hubalek (1974) in his analysis of terrestrial birds, mostly Passeriformes.

It is interesting that the nests in which the greatest richness and diversity of keratinomycete species were observed (mute swans and coots) differed considerably by keratin matter content (feathers). High amounts of feathers and excrements were observed in mute swan's nests while small amounts were noted in the coot's nests or they were absent (Tab. 2). On the other hand, the two birds' species had similar breeding biotopes and feeding grounds. Both colonized fertile reservoirs (ponds), built nests in reed beds and broadleaf cattail rushes, and mostly fed in the littoral zone (mute swans also in the middle of the ponds), feeding on vegetation and small invertebrates (snails, insects) occurring on plants and the bottom slime of shallow waters. A high rate of contamination of the nests by geophilic keratinophilic fungi may also have been connected with the contamination of the feeding grounds of these birds by the fungi. A high accumulation of geophilic keratinophilic fungi is observed in bottom sediments and reservoir waters affected by strong anthropopressure such as ponds (Korniłłowicz 1993; Ulfig 1986, 1987; Ulfig, Ulfig 1990; Ulfig et al. 1996). Allochthonic organic substances, including keratin remains (feathers, hair, 
etc.), are a source of these fungi (Korniłłowicz 1993; Ulfig et al. 1996). It is highly probable that the fungi may have been mechanically transferred on the plumage or collected by the birds with the food. The fact that the frequency and the distribution of keratinophilic fungi on the surface of birds' bodies depends on their feeding habitats was previously reported by Pugh $(1965,1966)$.

Bird excrements may also have been a source of keratinophilic fungi in the nests of many bird species. Faeces contamination was observed especially in the case of grey herons, mute swans and marsh harriers (Tab. 2). The occurrence of keratinophilic fungi in excrements and their spread by excretion with faeces have been reported by, e.g., Dominik, Majchrowicz (1970); Nooruddin, Singh (1987); Garetta et al. (1992).

Prey remains were also an important contribution to the keratinolytic mycobiota in the nests of marsh harriers and grey herons: birds, small mammals (marsh harriers), hair (grey herons), and pellets (both species). Bird plumage, mammal hair, skin scales and pellets are obviously colonised by different species of geophilic dermatophytes and Chrysosporium (Pugh 1966; Rees 1967; Pugh, Evans 1970; Hubalek et al. 1973; Hubalek 1974; Sur, Ghos 1980; Korniłłowicz-Kowalska, Kitowski 2009).

The thesis that feeding habitats and "animalisation" (enrichment in keratin remains) are mostly a source of keratinophilic fungi in the nests of wetland birds is also corroborated by the observations of breeding biotopes and feeding grounds of other bird species examined in the study. Few species of keratinophilic fungi were recorded in the nests of these birds (great crested grebe, black-headed gull, common tern and black tern). Bird feathers or excrements were also observed in them sporadically. Apart from black terns, these birds are piscivorous, search for fish in the water, diving into it (great crested grebe) or catching fish from the air (blackheaded gull, common tern). Black terns, on the other hand, are insectivores and catch insects in flight, over the water surface and fields. This manner of feeding and the types of feeding sites (in the water, air above the reservoir) are not favourable for the acquisition by birds of geophilic keratinophilic fungi that can occur in these environments only accidentally.

The majority of bird species examined did not come into contact with the soil (an environment believed to be a major reservoir of geophilic keratinophilic fungi) or such contact was rare. Marsh harriers which often hunt outside the breeding site, in meadows and fields, catching small mammals, lagomorphs, sometimes poultry, and grey herons which supplement their diet with voles outside the breeding season, were the only exceptions. Little importance of the soil as a source of contamination of the plumage and nests of the majority of fungi was previously reported by Pugh (1966) and Rees (1967).

Our examinations show that non-dermatophytic keratinophilic fungi of the Chrysosporium group are a dominant group in the nests of wetland birds. They represented ca. $78 \%$ of the keratinophilic mycobiota of the nests (273 nests), while the genus Chrysosporium itself constituted ca. 63\%. The dominance of Chrysosporium in the nests of land birds was reported by Hubalek (1974) and Hubalek et al. (1973) several times. In their analysis of the nests of passerines, mostly Eurasian tree sparrow Passer montanus, Hubalek et al. (1973) showed that "chrysosporia" constituted over $90 \%$ of keratinomycete populations in the nests. Dermatophytes ranged only from ca. $2 \%$ to ca. $9 \%$ of the fungi (Hubalek et al. 1973). The share of geophilic 
dermatophytes was between $0 \%$ (both species of terns and gulls) and $44.3 \%$ (mute swan) in the nests of wetland birds studied.

A generally higher frequency of Chrysosporium in comparison with geophilic dermatophytes in birds' nests may be connected with their higher occurrence in the plumage and on birds' feathers (Hubalek 2000) and a lower keratinolytic activity (Korniłłowicz-Kowalska 1997; Kunert 2000). Due to the latter, these fungi grow better in environments containing more accessible keratin sources, such as feather keratin rather than, for instance, hair keratin. Moreover, nest $\mathrm{pH}\left(\mathrm{pH}\right.$ in $\mathrm{H}_{2} \mathrm{O}$ 6.5-7.8) was a factor favourable for a high frequency of Chrysosporium in the nests of wetland birds examined. The majority of Chrysosporium species prefer environments with a higher $\mathrm{pH}$ and are alkalotolerant (Kushwaha 2000).

Ch. keratinophilum was the most frequently isolated species from the nests of wetland birds. Together with its telefomorph (Aphanoascus fulvescens), it colonised the nests of all the birds and its share in the community of keratinophilic fungi was $53 \%$ on average. Ch. tropicum (11.5\% of total keratinomycetes), isolated mostly from the nests of grey herons, was less widespread. According to Hubalek (1974), A. fulvescens mostly colonises nests of wetland birds and $\mathrm{Ch}$. tropicum is a frequent coloniser of these nests.

Trichophyton terrestre, which together with its teleomorphs (Arthroderma quadrifidum and $A$. insingulare) constituted $12.5 \%$ of all isolated fungi, and Microsporum gypseum and its telefomorph (Nannizzia gypsea), which constituted $7.1 \%$, had the highest frequency among geophilic dermatophytes. Populations of T. terrestre mostly colonised the nests of marsh harriers and grey herons while M. gypseum colonised the nests of mute swans.

The frequency and distribution of individual keratinomycete populations in the nests of wetland birds was conditioned primarily by the differences in the humidity and $\mathrm{pH}$ level of the nests. A similar phenomenon was observed in a study on the frequency of keratinomycetes in the soil by Chmel et al. (1972) as well as by Korniłłowicz (1993) and Korniłłowicz-Kowalska, Bohacz (2002). Soil pH was the most important selection factor in the populations of these fungi (Korniłłowicz 1993; Korniłłowicz-Kowalska, Bohacz 2002).

The present investigations show that a high humidity of the nest material was the reason for the accumulation of Ch. keratinophilum in the nests of wetland birds. The occurrence frequency of the fungus increased as water content increased $(\mathrm{r}=0.62, \mathrm{p}=0.05)$. The colonisation of nests with a high humidity level (ok. 62\%) by Ch. keratinophilum was also observed by Hubalek et al. (1973), who reported that Ch. keratinophilum (as a teleomorph) is isolated more frequently from the plumage of water birds than land birds. Ch. keratinophilum's preference for environments with a high level of humidity results from its hygrophilous (hydrotolerant) nature, which is related to a high demand for water (Garg et al. 1985; Hubalek 2000). Ch. keratinophilum is also an alkalotolerant species. A reverse relationship with the humidity level in the nests was observed in the population of Trichophyton terrestre, a species belonging to xerophyles (Garg et al. 1985). The frequency of occurrence of this dermatophyte decreased together with an increase in the water content in the nest material $(\mathrm{r}=-0.61, \mathrm{p}=0.05)$. T. terrestre's preference for dry environments was also observed by Chmel et al. (1972) and Chmel \& Vláčiliková (1975). 
The present investigations also confirm growth stimulation of T. terrestre in alkaline environments previously observed by other authors (Chmel et al. 1972; Ulfig et al. 1996). The frequency of this dermatophyte increased as $\mathrm{pH}$ increased $(\mathrm{r}=0.81$, $\mathrm{p}=0.05$ ) reaching its maximum in the nests of grey herons in which $\mathrm{pH}$ in $\mathrm{H}_{2} \mathrm{O}$ was ca. 7.4-7.8. In the case of T. terrestre, a high content of N-total, phosphorus and calcium was also a factor significantly conditioning its frequency of occurrence in the nests. It may be supposed that a high level of these elements contributed primarily to a $\mathrm{pH}$ increase in the nests. Nest alkalisation was caused by the release of ammonia produced during the ammonification of uric acid contained in bird faeces (accumulated in very high amounts in the nests of grey herons) and calcium ions and phosphates from the digestion of animal food (fish) and excreted in faeces. The relationship between the frequency of $T$. terrestre and the calcium level in the environment (soil) was reported by Chmel et al. (1972).

Microsporum gypseum is also interesting in the group of other, more frequently isolated species of keratinophilic fungi. Although no significant correlations between its frequency of occurrence (the number of samples with fungal growth was too small) and the physico-chemical properties of the nests were observed, its occurrence limited mostly to the nests of mute swans and coots may suggest preferences for environments with neutral $\mathrm{pH}$ and a relationship with biotopes polluted with organic matter. M. gypseum is a dominant dermatophyte species in bottom sediments of waters strongly polluted by communal waste waters delivering considerable amounts of keratin matter (Ulfig 2000). Similar observations were made on the occurrence of $M$. gypseum in soils polluted with waste waters (Ali-Stayech, Jamous 2000). Previous analyses (Korniłłowicz-Kowalska, Bohacz 2002) of the occurrence and the distribution of geophilic dermatophytes and Chrysosporium in soils with different physico-chemical properties showed that $M$. gypseum (as well as $M$. cookei) colonises exclusively soils characterised by a considerable "animalisation" and neutral $\mathrm{pH}$.

It should be stressed that the majority of keratinomycete species recorded more frequently in the nests of wetland birds were thermotolerant fungi such as Ch. keratinophilum, Ch. tropicum, M. gypseum. They grow well at a temperature of $37^{\circ} \mathrm{C}$ and maximum growth temperatures are $40-41^{\circ} \mathrm{C}$ (Garg et al. 1985). This is consistent with nest temperatures during incubation reaching a maximum of $40-41^{\circ} \mathrm{C}$ (Pinowski et al. 1999).

On the other hand, species considered to be typical soil species such as Trichophyton ajelloi and Ctenomyces serratus (Domsch et al. 1980) were rare in the nests. Neutral or alkaline $\mathrm{pH}$ of the nests of wetland birds did not encourage the occurrence of acidophilic species such as T. ajelloi, Arthroderma uncinatum, A. curreyi (Garg et al. 1985). The exception was Chrysosporium tropicum, which is thought to be acidophilic according to Garg et al. (1985). It occurred relatively frequently in the nests of grey herons where $\mathrm{pH}\left(\mathrm{H}_{2} \mathrm{O}\right)$ was from 5.99 to 7.76. Hubalek et al. (1973) also reported the occurrence of $\mathrm{Ch}$. tropicum in nests with $\mathrm{pH}$ ranging from acidic of slightly alkaline ( $\mathrm{pH}$ 5.5-7.5). It is possible that the species colonises biotopes with a broad $\mathrm{pH}$ range, adapted mostly to high temperatures (van Oorschot 1980) and resistant to light. Extreme conditions are observed in grey heron's nests during breeding: low humidity, sun exposure and additional nest heating related to it. This allows only species of keratinomycetes, such as T. terrestre and Ch. tropicum, that are most resistant to the lack of water and insolation, to survive. 
Of the species of keratinophilic fungi recorded in the nests of wetland birds, a widespread occurrence and a high frequency of Ch. keratinophilum in many nests and the accumulation of $M$. gypseum in the nests of mute swans may raise greatest concerns. Ch. keratinophilum and its teleomorph Aphanoascus fulvescens are opportunistic non-dermatophitic causal agents of mycoses in humans and animals (Gueho et al. 1985). Microsporum gypseum is the most virulent geophilic dermatophyte causing inflammatory tinea corporis and tinea capitis in humans (Hayashi, Toshitani 1983; Offidani et al. 1998). It also causes mycoses in animals (Garetta et al. 1992).

The results obtained in this study also confirmed the occurrence of populations of potentially pathogenic ubiquistic moulds, Aspergillus fumigatus and Scopulariopsis brevicaulis, in the nests, observed in a previous study (Korniłłowicz-Kowalska, Kitowski 2009). The species are thermotolerant and alkalotolerant, and show keratinolytic abilities (Kozakiewicz, Smith 1994; Santos et al. 1996; Filipello-Marchisio et al. 2000). Pathogenic strains of these fungi cause lung aspergillosis (A. fumigatus) and onychomycosis (S. brevicaulis) (Dvořak, Otčenašek 1969). Aspergillus fumigatus is very frequently isolated from nests of birds, their ontocoenoses, plumage and pellets (Hubalek 1974; Kruszewicz et al. 1995; Shin et al. 1996; Korniłłowicz-Kowalska, Kitowski 2009). It is the most frequent causal agents of mycoses, mostly of the lungs and air sacs in wetland birds (Mikaelian et al. 1997). The present investigations show that nests are a potential source of pathogenic infections with $A$. fumigatus in wetland birds. They are also some of reservoirs of geophilic fungi causing dermatomycoses and systemic mycoses in humans and mammals. These fungi can penetrate the water body from the nest and can be transferred by birds over considerable distances during migration.

Acknowledgement. This work was supported by the Polish Committee of Scientific Researches, grants no. 2P04G03330.

\section{REFERENCES}

Ali-Stayech, Jamous R.M.F. 2000. Keratinophilic fungi and related dermatophytes in polluted soil and water habitats. (In:) R.K.S., Kushwaha, J. Guarro (eds). Biology of dermatophytes and other keratinophilic fungi. Rev. Iber. Micol. 17: 51-59.

Böhme H., Ziegler H. 1969. The distribution of geophilic dermatophytes and other keratinophilic fungi in relation to the $\mathrm{pH}$ of the soil. Mycophatol. Mycol. Appl. 38: 247-255.

Chmel L., Vláčiliková A. 1975. The ecology of keratinophilic fungi at different depths of soil. Sabouraudia 13: 185-191.

Chmel L., Hasilíková A., Hrašco J., Vláčiliková A. 1972. The influence of some ecological factors on keratinophilic fungi in the soil. Sabouraudia 10: 26-34.

Currah R.S. 1985. Taxonomy of the Onygales: Arthrodermataceae, Gymnoascaceae, Myxotrichaceae and Onygenaceae. Mycotaxon 24: 1-216.

Dominik T., Majchrowicz I. 1970. Further contribution to the knowledge of keratinolytic and keratinophilic fungi of the region of Szczecin - keratinolytic and keratinophilic fungi in the excrements of farm animals. Ekol. Pol. S.A. 18: 571-611.

Domsch K.H., Gams W., Anderson T.H. 1980. Compendium of Soil Fungi. I. Acad. Press. London.

Dvořak J., Otčenašek M. 1969. Mycological Diagnosis of Animal Dermatophytoses, Academia. Praque.

Ellis H.B. 1971. Dematiaceous Hyphomycetes. Commonwelth. Mycological Institute Kew Surrey, England.

English M.P. 1963. The saprophytic growth of keratinophilic fungi on keratin. Sabouraudia 2: 115-130.

English M.P. 1965. The saprophytic growth of non-keratinophilic fungi on keratinized substrate and a comparison with keratinophilic fungi. Trans. Br. Mycol. Soc. 48: 219-235.

English M.P. 1969. Destruction of hair by Chrysosporium keratinophilum. Trans. Br. Mycol. Soc. 52: 247255. 
Filipello-Marchisio V. 2000. Keratinophilic fungi: their role in nature and degradation of keratinic substrates. (In:) R. K. S. Kushwaha, J. Guarro (eds). Biology of dermatophytes and other keratinophilic fungi. Rev. Iber. Micol. 17: 86-92.

Filipello-Marchisio V., Fusconi A., Querio F.L. 2000. Scopulariopsis brevicaulis: a keratinophilic or a keratinolytic fungus. Mycoses 43: 281-282.

Garetta G., Piontelli E. 1975. Isolation of keratinophilic fungi from soil of Pavia Italy. Sabouraudia 13: 33-37.

Garetta G., Mongiarotti A.M., Piontelli E. 1992. Keratinophilic fungi isolated from soil of Italian parks in the province of Pavia. Eur. J. Epidemiol. 8: 330-339.

Garg A.P., Gandotra S., Mukerji K.G., Pugh G.J.F. 1985. Ecology of keratinophilic fungi. Proc. Indian Acad. Sci. (Plant Sci.) 94: 149-163.

Gueho E., Villard J., Guinet R. 1985. A new human case of Anixiopsis stercoraria mycosis: discussion of its taxonomy and pathogenicity. Mycoses 28: 430-436.

Hayashi N., Toshitani S. 1983. Human infections with Microsporum gypseum in Japan. Mycoses 26: $337-$ 345.

Hubalek Z. 1974. Fungi associated with free-living birds in Czechoslovakia and Yugoslavia. Acta Sc. Nat. Brno 8 (3): 1-62.

Hubalek Z. 1976. Occurrence of keratinolytic fungi in nests of tree sparrow (Passer montanus L.) in relation to the substrate moisture (in Czech). Ces. Mykol. 30: 106-109.

Hubalek Z. 2000. Keratinophilic fungi associated with free living mammals and birds (In:) R. K. S. Kushwaha, J. Guarro (eds). Biology of dermatophytes and other keratinophilic fungi. Rev. Iber. Micol. 17: 104-108.

Hubalek Z. 2004. An annotated checklist of pathogenic microorganisms associated with migratory birds. J. Wild. Diseas. 40: 639-659.

Hubalek Z., Balat F. 1974. The survival of microfungi in the nests of tree sparrow (Passer montagus L.) in the nest-boxes over the winter season. Mycopathologia 54: 517-530.

Hubalek Z., Balat F., Touškova I., Vlk T. 1973. Mycoflora of birds' nests in nest-boxes. Mycopath. Mycol. Appl. 49: 1-12.

Korniłłowicz T. 1992. Badania nad mikoflorą zasiedlającą surowe odpady keratynowe w glebie. Acta Mycol. 27: 231-245.

Korniłłowicz T. 1993. Występowanie geofilnych grzybów keratynofilnych w osadach dennych jezior o różnej trofii. Acta Mycol. 28: 171-184.

Korniłłowicz T. 1994. Methods for determining keratinolytic activity of saprophytic fungi. Acta Mycol. 29: $169-178$.

Korniłłowicz-Kowalska T. 1997. Studies on the decomposition of keratin wastes by saprotrophic microfungi. I. Criteria for evaluating keratinolytic activity. Acta Mycol. 32: 51-79.

Korniłłowicz-Kowalska T. 1999. Studies on decomposition of keratin wastes by saprotrophic microfungi. III. Activity and properties of keratinolytic enzymes. Acta Mycol. 34: 65-78.

Korniłłowicz-Kowalska T., Bohacz J. 2002. Some correlations between of occurrence frequency of keratinophilic fungi and selected soil properties. Acta Mycol. 37 (1/2): 101-116.

Korniłłowicz-Kowalska T., Wojdyło-Kotwica B. 2008. Onygenales (p.p.); Hyphomycetes: Chrysosporium (p.p.), Microsporum (p.p.), Trichophyton (p.p.) (In:) W. Mułenko, T. Majewski, M. Ruszkiewicz-Michalska (eds). A preliminary checklist of micromycetes in Poland. Biodiversity of Poland. 9. W. Szafer Institute of Botany, Polish Academy of Sciences, Kraków.

Korniłłowicz-Kowalska T., Kitowski I. 2009. Diversity of fungi in nests and pellets of Montagu's Harrier (Circus pygargus) from east Poland - importance of chemical and ecological factors. Ecol. Chem. Enngineer. S. 16 (4): 453-471.

Kozakiewicz Z., Smith D. 1994. Physiology of Aspergillus (In:) R. F. Atkins, R. F. Sherwood (eds). Biotechnology Handbooks 7. Aspergillus. Plenum Press, New York.

Krebs C.J. 1994. Ecology. The Experimental Analysis of Distribution and Abundance, Fourth Edition. Harper Collins, New York, USA

Kruszewicz A.G., Pinowski J., Kruszewicz A.H., Mazurkiewicz M., Pawiak R., Małyszko E. 1995. Occurrence of fungi in House Sparrow (Passer domesticus) and Tree Sparrow (Passer montanus) nestlings. (In:) J. Pinowski, B.P. Kavanagh, B. Pinowska (eds). Nestling mortality due to microorganism and toxic substances: synthesis. PWN Polish Scientific Publishers, Warszawa, pp. 283-290. 
Kunert J. 1973. Keratin decomposition by dermatophytes. I. Sulfite production as possible way of substrate denaturation. Zeitschrift für Allg. Mikrobiol. 13: 489-498.

Kunert J. 1976. Keratin decomposition by dermatophytes. II. Presence of S-sulfocysteine and cysteic acid in soluble decomposition products. Zeitschrift für Allg. Mikrobiol. 16: 97-105.

Kunert J. 1989. Biochemical mechanism of keratin degradation by the actinomycetes Streptomyces fradiae and the fungus Microsporum gypseum: A comparison. J. Basic. Microbiol. 29: 597-604.

Kunert J. 2000. Physiology of keratinophilic fungi. (In:) R. K. S. Kushwaha, J. Guarro (eds). Biology of dermatophytes and other keratinophilic fungi. Rev. Iber. Micol. 17: 77-85.

Kushwaha R. K .S. 2000. The genus Chrysosporium, its physiology and biotechnological potential (In:) R. K. S. Kushwaha, J. Guarro (eds). Biology of dermatophytes and other keratinophilic fungiRev. Iber. Micol. 17: 66-76.

Mercer E. H. 1958. The fine structure keratin. Textile Research J. 28: 860-866.

Mikaelian J., Gauthier F., Fitzgerald G., Higgins R., Clavean R., Martinean D. 1997. Primary causes of death in wild birds of Quebec. Med. Vet. Quebec. 27: 94-102.

Montovani A., Morganti D., Battelli G., Montovani A.P., Poglayeni G., Tampieri M.P., Vecchi G. 1982. The role of wild animals in the ecology of dermatophytes and related fungi. Folia Parasitol. 29: $79-84$.

Nooruddin N., Singh B. 1987. Prevalance of dermatophytes and keratinophilic fungi in soil and dried dung of the premises of buffalo sheds. Mycoses 30: 589-593.

Offidani A., Simoncini C., Arzeni D., Cellini A., Amerio P., Scalise G. 1998. Tinea capitis due to Microsporum gypseum in an adult. Mycoses 41: 239-241.

Oorschot van C.A.N. 1980. A revision of Chrysosporium and allied genera. Studies Mycol. 20. 89 pp.

Otčenašek M., Hudec K., Hubalek Z., Dvořak J. 1967. Keratinophilic fungi from the nests of birds in Czechoslovakia. Sabouraudia 5: 350-354.

Peberdy J.F. 1987. Penicillium and Acremonium. Biotechnology Handbooks. v.1 Plenum Press. New York.

Pinowski J., Pinowska B., Haman A. 1999. Fungi in birds' plumage and nests. Intern. Stud. Sparrows 26: 3-28.

Pugh G.J.E. 1965. Cellulolytic and keratinophilic fungi recorded on birds. Sabouraudia 4: 85-91.

Pugh G.J.E. 1966. Associations between birds, nests, their $\mathrm{pH}$ and keratinophilic fungi. Sabouraudia 5: 43-53.

Pugh G.J.E., Evans M.D. 1970. Keratinophilic fungi associated with birds. I. Fungi isolated from feathers nests and soil. Trans. Br. Mycol. Soc. 54: 233-240.

Rees R.G. 1967. Keratinophilic fungi from Queensland I. Isolation from animal hair and scales. Sabouraudia 5: 165-172.

Rippon J.W. 1982. Medical Mycology. The pathogenic fungi and the pathogenic Actinomycetes. Saunders W.B. Company Philadelphia.

Santos R.M.D.B., Firmino A.P., de Sa C.M., Felix C.R. 1996. Keratinolytic activity of Aspergillus fumigatus Fresenius. Curr. Microbiol. 33: 364-370.

Shin T.K., Lee H.J., Lee D.S., Kwon O.D., Yang K.C., Kim O.N., Kim W.T. 1996. Aspergillus fumigatus infection in wild goose. Korean J. Vet. Clin. Med. 13: 195-197.

Sur B., Ghosh G.R. 1980. Keratinophilic fungi from Orissa, India. II. Isolation from feathers of wild birds and domestic fowls. Sabouraudia 18: 275-280.

Takatori K., Hasegawa A. 1981. Isolation of keratinophilic and non-keratinophilic fungi from birds' nests. Trans. Mycol. Soc. (Japan) 22: 347-352.

Trojan P. 1975. Ekologia ogólna. Wyd. PWN, Warszawa.

Ulfig K. 1986. Dermatofity w osadach dennych i osadach ściekowych. Post. Dermatol. 3: 385-389.

Ulfig K. 1987/1990. Grzyby keratynofilne w osadach dennych wód powierzchniowych. Acta Mycol. 23: 3-11.

Ulfig K. 2000. The occurrence of keratinolytic fungi in waste and waste-contaminated habitats. (In:) R.K.S., Kushwaha, J. Guarro (eds). Biology of dermatophytes and other keratinophilic fungi. Rev. Iber. Micol. 17: 44-50.

Ulfig K., Lukasik W., Plaza G. 1996. Further statistical evaluation of the occurrence of keratinolytic fungi in dam sediments. Intern. J. Environ. Health Res. 6: 39-47.

Ulfig K., Ulfig A. 1990. Keratinophilic fungi in bottom sediments of surface waters. J. Med. Vet. Mycol. 28: 419-422. 
Dermatofity geofilne oraz inne grzyby keratynofilne w gniazdach ptaków wodno-błotnych

\section{Streszczenie}

W prezentowanej pracy zbadano częstość występowania oraz skład gatunkowy grzybów keratynofilnych w 38 gniazdach 9 gatunków ptaków wodno-błotnych. Gniazda zbierano w latach 2006-2009 na terenie Lubelszczyzny (płd.-wsch. Polska), po opuszczeniu przez ptaki. Posługując się metodą przynęty keratynowej przebadano 390 próbek materiału gniazdowego, uzyskując 348 szczepy keratinomycetes. Obecność grzybów keratynofilnych stwierdzono w $86,8 \%$ badanych gniazd. Były one reprezentowane przez 9 gatunków dermatofitów geofilnych oraz 13 gatunków Chrysosporium. 78\% wyosobnionych szczepów stanowiły grzyby z grupy Chrysosporium, $22 \%$ należało do dermatofitów geofilnych. Gatunkiem dominującym był $C h$. keratinophilum, który wraz z teleomorfą (Aphanoascus fulvescens) reprezentował 53\% keratynolitycznej mykobioty badanych gniazd. Do mniej licznych ale częstych należały populacje: Ch. tropicum (11,5\%), Trichophyton terrestre wraz z teleomorfą (12,5\%) oraz Microsporum gypseum włącznie z teleomorfą $(7,1 \%)$. Wyselekcjonowane populacje reprezentowały głównie grzyby termotolerancyjne, preferujące środowiska o odczynie obojętnym i alkalicznym $(C h$. keratinophilum, A. fulvescens, T. terrestre, M. gypseum) oraz o dużej wilgotności (Ch. keratinophilum). Przeprowadzone badania wykazały, że gniazda ptaków wodno-błotnych cechują się wysoką frekwencją takich gatunków grzybów potencjalnie chorobotwórczych dla ptaków, ssaków oraz człowieka jak M. gypseum, Ch. keratinophilum i Aspergillus fumigatus. 